\title{
Advanced Exergy, Exergoeconomic, and Exergoenvironmental Analyses of Integrated Solar-Assisted Gasification Cycle for Producing Power and Steam from Heavy Refinery Fuels
}

\author{
Esmaeil Jadidi ${ }^{1,2}$, Mohammad Hasan Khoshgoftar Manesh ${ }^{1,2, *} \mathbb{C}$, Mostafa Delpisheh ${ }^{1} \mathbb{C}$ \\ and Viviani Caroline Onishi ${ }^{3, *(\mathbb{D}}$ \\ 1 Energy, Environmental and Biological Systems Research Lab (EEBRlab), Division of Thermal Sciences and \\ Energy Systems, Department of Mechanical Engineering, Faculty of Technology \& Engineering, \\ University of Qom, Qom 3716146611, Iran; Esmaeil.Jadidi@gmail.com (E.J.); Mostafa@Delpisheh.com (M.D.) \\ 2 Center of Environmental Research, Qom 3716146611, Iran \\ 3 School of Engineering and the Built Environment, Edinburgh Napier University, Merchiston Campus, \\ 10 Colinton Road, Edinburgh EH10 5DT, UK \\ * Correspondence: M.Khoshgoftar@qom.ac.ir (M.H.K.M.); V.Onishi@napier.ac.uk (V.C.O.)
}

\section{check for} updates

Citation: Jadidi, E.; Khoshgoftar Manesh, M.H.; Delpisheh, M.; Onishi, V.C. Advanced Exergy,

Exergoeconomic, and

Exergoenvironmental Analyses of Integrated Solar-Assisted Gasification Cycle for Producing Power and Steam from Heavy Refinery Fuels. Energies 2021, 14, 8409. https://doi.org/ $10.3390 /$ en14248409

Academic Editor: David Borge-Diez

Received: 15 November 2021

Accepted: 9 December 2021

Published: 13 December 2021

Publisher's Note: MDPI stays neutral with regard to jurisdictional claims in published maps and institutional affiliations.

Copyright: (c) 2021 by the authors. Licensee MDPI, Basel, Switzerland. This article is an open access article distributed under the terms and conditions of the Creative Commons Attribution (CC BY) license (https:/ / creativecommons.org/licenses/by/ $4.0 /)$.

\begin{abstract}
Integrated solar-assisted gasification cycles (ISGC) have emerged as a more flexible and environmentally friendly solution for producing power, steam, and other high-valued by-products from low-cost opportunity fuels. In this light, this paper investigates a new ISGC system for converting heavy refineries fuels into power and steam utilities while enhancing energy efficiency and economic and environmental performance indicators. In this approach, a solar energy field and a two-pressure heat recovery steam generator were integrated into the ISGC system to improve overall economic and environmental plant viability. The ISGC system was modelled in MATLAB software, and the results were validated using Thermoflex software. Conventional and advanced energy, exergy, exergoeconomic, and exergoenvironmental (4E) analyses were implemented to assess the main performance parameters and identify potential system improvements. The ISGC system produced $319.92 \mathrm{MW}$ of power by feeding on $15.5 \mathrm{~kg} / \mathrm{s}$ of heavy refinery fuel, with a thermal efficiency of $50 \%$ and exergy efficiency of $54 \%$. The results also revealed an investment cost of $\$ 466$ million, evaluated at a system cost rate of $446 \$ / \mathrm{min}$ and an environmental impact rate of $72,796 \mathrm{pts} / \mathrm{min}$. The conventional and advanced $4 \mathrm{E}$ analyses unveiled the process economic and environmental feasibilities, particularly for oil-rich countries with high availability of solar resources.
\end{abstract}

Keywords: solar-aided gasification cycles; heavy refinery fuels; energy and exergy analysis; 4E analyses; integrated economic and environmental analyses; energy recovery systems; renewable energy

\section{Introduction}

Integrated gasification combined cycles (IGCC) have received increased interest over the past few years as a more sustainable solution for the co-generation of power, steam, and other valuable by-products from heavy refinery residues. The high flexibility of IGCC systems on the input feed makes them very attractive for employment in various applications subjected to fuel availability and costs. In this way, a wide range of solid and liquid wastes can be used as base input fuel, including coal, municipal wastes, heavy liquid refinery residues (heavy oil), solid refinery waste (petroleum coke), and biomass, among others [1]. IGCC power systems provide improved economic viability to existing and new processing plants owing to their ability to generate power from syngas and additional high-valued utilities and feedstock chemical co-products (e.g., ammonia, methanol, etc.) from low-cost fuels [2,3]. Additional advantages include low production costs and the potential to meet tighter pollutant emissions standards on $\mathrm{SO}_{\mathrm{x}}, \mathrm{NO}_{\mathrm{x}}$, and particulates. IGCC systems also offer the possibility of reducing $\mathrm{CO}_{2}$ emissions via pre-combustion 
gas purification, carbon capture and storage (CCS) [4], and gas switching combustion (GSC) technology [5]. Even though recent advances in gasification, syngas cleanup, air separation, and gas turbine technologies have driven process costs down and increased system performance, challenges remain in further enhancing energy and environmental performance requirements. In this context, the integration of renewable energy (particularly solar energy) into IGCC systems emerges as an attractive alternative.

IGCC power systems are composed of three main sections, namely, gasification, cleanup, and combined cycle [6]. The construction, operation, and maintenance of IGCC plants are generally more demanding than conventional power systems, eliciting an increase in capital investment and maintenance expenses and a reduction in reliability and availability [7]. Typically, IGCCs allow obtaining higher thermal efficiency over conventional coal-fired power plants (up to $60 \%$ when fueled with natural gas $[2,8]$ ), while the carbon emissions are lower than traditional power plants [7]. Another important benefit of IGCCs is the reduction of other pollutants. This is because the cycle allows the syngas to be purified after leaving the gasification reactor while a substantial amount of hydrogen sulphide and carbon dioxide is separated during the process [9]. In some cycles, the latter can be done via humidification, with the advantage of optimizing the amount of hydrogen produced in the syngas stream [10]. In an IGCC plant, oxygen blow technology can also be used in the gasification reactor to prevent nitrogen gas from interfering in the gasification process, by prompting a binding effect in reducing the toxic $\mathrm{NO}_{x}$ pollutant [11].

Nag et al. [12] performed energy and exergy analyses of a combined cycle with a fixed bed gasifier. Their results showed that the gasification reactor unit displayed the highest energy loss among other cycle components. Moreover, their exergy analysis results revealed that the temperature ratio did not influence the highest exergy destruction of the gasification process, whereas the pressure ratio had also a low effect. The authors concluded that the exergy destruction in the combustor can be reduced by increasing temperature and pressure ratios. Emun et al. [13] simulated an IGCC system employing a Texaco gasifier using Aspen Plus ${ }^{\circledR}$ software. The system was operated via gasification using slurry based on a coal-water mixture (35.5\% $w / w$ water). Their results showed that the proposed process can achieve up to $45 \%$ thermal efficiency with a substantial decrement in $\mathrm{SO}_{\mathrm{x}}$ and $\mathrm{CO}_{2}$ emissions, reaching $0.15 \mathrm{~kg} / \mathrm{MWh}$ and $698 \mathrm{~kg} / \mathrm{MWh}$, respectively.

Domenichini et al. [14] investigated hydrogen and power generation through a system fueled by refinery waste via pinch analysis. Their proposed approach was based on oxygen blow-entrained bed gasification, which was sized to produce a considerable hydrogen amount and feed gas turbines of the combined cycle unit. The authors focused on the heat integration among syngas cooling and sections of the combined cycle and reported a cost of $34 € / t$ for avoiding $\mathrm{CO}_{2}$ emissions. Additionally, they concluded that the cost of electricity was attractive, with a hydrogen price of 9.5 cents $/ \mathrm{Nm}^{3}$, highlighting the advantage of the combined production. Morini et al. [15] simulated an IGCC cycle with a 650-MW gasification unit. In addition, the authors considered an air-cooled driven gas turbine, in which the inlet air cooling was achieved using liquid nitrogen spray. They also accounted for actual temperature profiles of various locations for an entire year in the modelling formulation. Their findings indicated that the system presented the highest performance for Johannesburg, when compared to conventional inlet air cooling schemes.

Zhang and Ahn [16] investigated the prospects of two IGCCs in China for achieving near-zero emissions. Their proposed system was based on a pre-combustion gasification process with carbon dioxide adsorbent and sour and sweet shifts. The authors reported that the sweet shift required 4.6-fold more shift steam than the sour one due to the low amount of steam in the syngas after the removal of $\mathrm{H}_{2} \mathrm{~S}$. Khoshgoftar Manesh and Jadidi [17] assessed the performance of a biomass-based IGCC fueled with olive pits by applying energy, exergy, exergy-economic, and exergy-environmental (4E) analyses. Their results indicated an output power of the IGCC of approximately $387.3 \mathrm{MW}$, with a cost of $5.23 \mathrm{US}$ /s and pollutants emissions of $41.72 \mathrm{mpts} / \mathrm{s}$. Moreover, their results demonstrated that the gasifier had the largest exergy destruction rate, which accounted for a $24 \%$ share. The authors also 
showed that the gasifier and combustion chamber units had the highest avoidable exergy destructions, while the scrubber presented the lowest one. Szima et al. [5] implemented a techno-economic analysis of hydrogen and power production from the IGCC plant. The authors employed the gas switching combustion (GSC) for carbon capture, whereas membrane-assisted water gas shift (MAWGS) reactors were used for hydrogen production. Table 1 displays a brief overview of the most recent literature regarding applications, methodologies, and practices related to IGCCs.

Table 1. A brief review of the most recent literature on the applications, methods, and practices related to integrated gasification combined cycles (IGCCs).

\begin{tabular}{|c|c|c|}
\hline Year & Authors & Study Summary \\
\hline 2015 & Morini et al. [15] & Simulation of a combined cycle with a 650-MW gasification unit. \\
\hline 2015 & Jia et al. [18] & $\begin{array}{l}\text { Simulation of a gasifier system with atmospheric solid oxide fuel cell, and investigation of the } \\
\text { fuel cell electrical efficiency using two types of gasifiers: air and oxygen blower. }\end{array}$ \\
\hline 2015 & Doherty et al. [19] & $\begin{array}{l}\text { Simulation of a fuel cell cycle with biomass feed and evaluation of the effect of syngas } \\
\text { temperature on the system performance, under four different scenarios. }\end{array}$ \\
\hline 2015 & Chen et al. [20] & $\begin{array}{l}\text { Investigation of a coal gasification cycle combined with a fuel cell via exergy destruction } \\
\text { evaluation in equipment. }\end{array}$ \\
\hline 2015 & Wang et al. [21] & $\begin{array}{l}\text { Investigation of a combined cooling, heating, and power (CCHP) system with a biogas feed } \\
\text { gasification system, which uses an absorption chiller system. The largest share of exergy } \\
\text { destruction is related to the gasification unit. }\end{array}$ \\
\hline 2015 & Athari et al. [22] & Investigation of a gas turbine cycle with fog cooling and biomass gasification. \\
\hline 2016 & Perna et al. [23] & $\begin{array}{l}\text { Investigation of combined biomass and solar energy sources in a gasification cycle for } \\
\text { hydrogen production. }\end{array}$ \\
\hline 2016 & Yari et al. [24] & $\begin{array}{l}\text { Simulation of a solid oxide fuel cell at atmospheric pressure using a heat recovery system, } \\
\text { which used a gasification system with biomass feed to produce fuels. }\end{array}$ \\
\hline 2016 & Lv et al. [25] & $\begin{array}{c}\text { Assessment of the efficiency of an integrated system with gas turbine and fuel cell-based } \\
\text { biomass gasification. }\end{array}$ \\
\hline 2016 & Thattai et al. [26] & $\begin{array}{c}\text { Feasibility study on combining up to } 70 \% \text { of biomass resources with a coal feed in a 253-MW } \\
\text { cycle. }\end{array}$ \\
\hline 2016 & Khani et al. [27] & Simulation and optimization of a fuel cell and gas turbine using a genetic algorithm. \\
\hline 2018 & Park et al. [28] & Modelling and simulation of a gasification cycle under different economic scenarios. \\
\hline 2019 & Zhang and Ahn [16] & $\begin{array}{l}\text { Investigation of the prospects of gasification power plants in China with near-zero emissions, } \\
\text { using pre-combustion gasification with carbon dioxide adsorbent. }\end{array}$ \\
\hline 2020 & $\begin{array}{l}\text { Khoshgoftar Manesh and } \\
\text { Jadidi [17] }\end{array}$ & Assessment of biomass-based IGCC with olive pits as feed and implemented $4 \mathrm{E}$ analyses. \\
\hline 2021 & Szima et al. [5] & $\begin{array}{l}\text { Techno-economic analysis of hydrogen and power production from the IGCC plant with the } \\
\text { gas switching combustion (GSC) for carbon capture and membrane-assisted water gas shift } \\
\text { (MAWGS) reactors to produce hydrogen. }\end{array}$ \\
\hline 2021 & Bany Ata et al. [2] & $\begin{array}{l}\text { Heat integration optimization and sensitivity analysis of an IGCC system based on lignite } \\
\text { co-gasification and refuse-derived fuels for co-generating methanol and electricity. }\end{array}$ \\
\hline 2021 & Muhammad et al. [3] & $\begin{array}{c}\text { Thermodynamic and economic analysis of IGCC system for producing electricity, methane, } \\
\text { and ammonia. }\end{array}$ \\
\hline
\end{tabular}

Although previous studies constitute important contributions to the area, none considered energy, environmental, and economic analyses of integrated solar-aided gasification cycles for enhancing energy recovery from low-cost opportunity fuels. It should be noted that solar-aided IGCC systems are among the most efficient and cleanest methods for converting solid wastes and refinery residues into valuable power and heat utilities and other high-value chemical by-products needed by the refineries. For surpassing limitations on preceding research, this paper investigates a new integrated solar-assisted gasification 
cycle (ISGC) for producing steam and power from heavy refinery fuels while enhancing energy efficiency, economic, and environmental performance indicators. In the proposed cycle, the syngas from the gasifier enters the turbine to produce power after purification and separation of pollutants, and then it is sent to the steam section for thermal energy recovery. In addition, a solar energy field, a two-pressure heat recovery steam generator (HRSG), and $\mathrm{CO}_{2}$ capture unit are integrated into the plant to enhance the overall system efficiency while reducing carbon emissions. The ISGC system was modelled and simulated in MATLAB software, and the results were validated using Thermoflex software. Conventional and advanced $4 \mathrm{E}$ analyses were implemented to assess energy, economic, and environmental ISGC system performances. The $4 \mathrm{E}$ analyses allows examining system units with an increased level of detail and thereby prioritize these equipment pieces for future optimization and improvement. Hence, the new approach provides a novel avenue towards dealing with heavy refinery fuels and turning an environmental issue into an opportunity, especially for oil-rich countries that enjoy high solar global irradiances. Major contributions and innovative features introduced by this study are highlighted as follows.

(1) Combined heat and power co-generation from gasification of low-cost heavy refinery fuels for achieving enhanced energy recovery.

(2) Solar-assisted energy generation via parabolic trough collectors to improve the overall system efficiency while reducing environmental impacts.

(3) Integration of $\mathrm{CO}_{2}$ absorber technology for further reducing pollutant emissions.

(4) Comprehensive conventional and advanced energy, exergy, exergoeconomic, and exergoenvironmental analyses to evaluate main performance parameters and identify potential system improvements.

\section{System Description}

The integrated solar-gasification cycle is based on the IGCC cycles proposed by Zhang et al. [29] and Khoshgoftar Manesh and Jadidi [17], which provide a suitable base combined-cycle configuration. Yet, the proposed new ISGC system encompasses a partial gasification cycle under oxygen blowing with a pre-combustion chamber, together with a solar energy field (parabolic through collectors), two-pressure heat recovery steam generator (HRSG) and a $\mathrm{CO}_{2}$ absorber, as depicted in Figure 1. It should also be noted that the study by Zhang et al. [29] used coal, and Khoshgoftar Manesh and Jadidi [17] employed biomass as feed for the IGCC power system. In contrast, the proposed ISGC plant is targeted at using heavy refinery fuel to take advantage of low-cost heavy refinery residues. Furthermore, conventional and advanced exergy, exergoeconomic, and exergoenvironmental evaluation are implemented to better shed light on the ISGC power system. Table A1 provides the operating conditions assumed for the different ISGC system units.

In the proposed ISGC system, the air first goes to the air separation unit (ASU), where the pure oxygen product stream (5) enters the gasifier. The superheated water vapor by the solar field is mixed with the heavy refinery fuel stream before entering the gasifier. In the syngas cooler, the heat from the syngas stream is utilized to saturate the water in the steam turbine. It should be observed that the fuel and syngas streams are represented by black lines in the schematic diagram in Figure 1, whilst the water and steam streams are depicted in blue, the flue products in red, and the air stream by red lines. The syngas enters the heat exchanger as stream (6), which is responsible for increasing the temperature of the humidified syngas. In the next section, the syngas goes to the $\mathrm{H}_{2} \mathrm{~S}$ remover unit in stream (10). Then, the syngas stream enters this unit as stream (4) to capture $\mathrm{CO}_{2}$. After entering the humidification section, the temperature of the syngas in the mentioned heat exchanger increases. Thereafter, the syngas pressure needs to be synchronized with the compressor outlet pressure. Hence, the syngas pressure is reduced by half of its initial value via an expander and produced energy. Herein, the syngas entered the combustion chamber (CC) as stream number (16). Finally, the combustion gases are sent to the gas turbine (GT) to provide electrical power. 




Figure 1. Schematic diagram of the proposed integrated solar-gasification cycle (ISGC) system (this diagram is adapted from Ref. [17]). AC: Air compressor; CC: Combustion chamber; HRSG: Heat recovery steam generator; GT: Gas turbine; ST: steam turbine.

In the HRSG unit, water enters the first cycle economizer as stream (42), and, after being saturated in the evaporator as stream (32), it goes to the first superheater to exchange heat with the flue gases to become superheated. Afterwards, this superheated steam enters the first turbine as stream (33). An additional water stream (1) entered the second economizer, before entering the syngas cooler as stream (11) to change phase from saturated liquid to saturated steam. It is then mixed with stream (27) and enters the second superheater. Here, superheated steam is sent to the second steam turbine (ST) with the stream (38). After power generation, this stream goes to the condenser, and, after condensation, it finally leaves it as a saturated liquid stream (22).

\section{Methodology}

The integrated solar-gasification cycle (ISGC) system was modelled in MATLAB software, and the thermodynamic results were validated via simulations using the Thermoflex software environment. Accordingly, the thermodynamic system modelling was performed in Thermoflex to obtain the streams pressure, temperature, and enthalpy. The developed code was based on the thermodynamic relations, input parameters (process operating conditions), and calculation of the unknown parameters, as indicated in Table A1 of Appendix A. Figure A1 shows the schematic of the computational procedure for the $4 \mathrm{E}$ analyses. The following sections outline the thermodynamic, economic, and environmental formulation used to assess the proposed ISGC system. 


\subsection{Thermodynamic Analysis}

Assuming a steady-state condition, the first law of thermodynamics was applied to all system components. Thus, the following mass balance was required for each equipment $k$ in the system.

$$
\sum \dot{m}_{i n, k}=\sum \dot{m}_{\text {out }, k}
$$

Equation (2) states the energy balance used for modelling each equipment $k$ in the system:

$$
\dot{Q}_{k}-\dot{W}_{k}=\sum \dot{m}_{\text {out }, k} h_{\text {out }, k}-\sum \dot{m}_{i n, k} h_{i n, k}
$$

where $\dot{m}, \dot{Q}, \dot{W}$, and $h$ denote the mass flow rate, heat transfer rate, power, and specific enthalpy, respectively.

For performing the thermodynamic analysis, the following assumptions were considered:

(1) Pressure drops were disregarded in heat exchangers and pipe network.

(2) Heat losses were neglected in the equipment.

(3) Turbines and pumps had isentropic efficiencies.

(4) Kinetic and potential energy and exergy changes were disregarded.

Additionally, the following assumptions were needed to model the gasifier [29]:

(1) Heat dissipation was neglected.

(2) The reactor was fed with heavy refinery fuel.

(3) The reactor type was an oxygen blower.

(4) The reactor included a syngas cooling heat exchanger.

(5) The air separation system was based on a membrane separation process.

\subsection{Conventional Exergy Analysis}

The aim of the conventional exergy analysis is to determine the exergy destruction and exergy efficiency of each component to better understand the irreversibilities of the system. In this study, exergy was divided into physical and chemical exergy, as given by Equation (3) and Equation (4), respectively:

$$
\begin{gathered}
e^{P H}=h-h_{0}-T_{0}\left(S-S_{0}\right) \\
e^{C H}=\sum x_{i} e_{i}^{0}+R T_{0} \sum x_{i} \ln x_{i} \gamma_{i}
\end{gathered}
$$

Herein, $h$ is enthalpy, $T$ is temperature, and $S$ denotes entropy. Additionally, $x_{i}$ is the mole fraction, $\gamma_{i}$ is component $i$ activity coefficients, and $e_{i}^{0}$ is the standard chemical exergy, addressed in Ref. [30]. The exergy rate of the $i$-th stream is obtained by the multiplication of the specific exergy rate by the corresponding mass flow rate:

$$
\dot{E}_{i}=\dot{m}_{i} \times e_{i}
$$

Exergy destruction is one of the critical parameters of the exergy analysis since it determined the system irreversibility rate. Ideal reversible systems present equal total inlet and outlet exergy flows. However, real systems are characterized by several sources of irreversibilities, including friction losses, transient heating, and chemical reactions, among others. As a result, the total exergy of output flows was lower than the one of the input flows to the system, which is expressed as the system exergy destruction. The Specific Exergy Costing (SPECO) [31] methodology was employed to measure the components' exergy destruction rate $\left(\dot{E}_{D, k}\right)$, as expressed by Equation (6). The method allowed stratifying exergy rates into fuel $\left(\dot{E}_{F, k}\right)$ and product $\left(\dot{E}_{P, k}\right)$ for each component (as given in Table A2). It should be noted that, unlike other methodologies, the SPECO approach accounts for fuel and product definitions and auxiliary cost equations at the component level, even in the 
most complex cases involving several exergy components. As a result, these definitions are independent of the entire system setup.

$$
\dot{E}_{D, k}=\dot{E}_{F, k}-\dot{E}_{P, k}
$$

The exergy efficiency is defined by:

$$
\varepsilon_{k}=\frac{\dot{E} x_{P, k}}{\dot{E} x_{F, k}}
$$

It is noteworthy that the chemical exergy of the fuel contributes to a larger share of the system input exergy:

$$
e x^{C H}=\beta \times L H V_{f u e l}
$$

where $\beta$ is the ratio of the exergy of the fuel over its low heating value (LHV), calculated by:

$$
\beta=\frac{1.044+0.16 \frac{H}{C}-0.34493 \frac{O}{C}\left(1+0.0531 \frac{H}{C}\right)}{1-0.4142 \frac{O}{C}}
$$

where $\mathrm{H} / \mathrm{C}$ and $\mathrm{O} / \mathrm{C}$ are the atomic ratios of the fuel. The formulation used for obtaining the exergy destruction and efficiency of system components is listed in Table A2 of Appendix A.

\subsection{Conventional Exergoeconomic Analysis}

By combining the exergy analysis with economic principles, such as investment, maintenance, and repair costs, the final cost of the exergy destruction can be evaluated for each system component. In this study, the flow costs based on exergoeconomic analysis included the investment cost rate, exergy destruction cost rate of each equipment, and the cost of fuel used in the system. The sum of these input costs represents the total cost of the entire system. Hence, the component cost rate is calculated by Equation (10).

$$
\dot{Z}_{k}=\frac{\Phi_{k} \times P E C_{k} \times C R F}{3600 \times N}
$$

where $\Phi_{k}$ is the maintenance factor (taken as 1.06), $N$ is the annual operating hours $(8000 \mathrm{~h})$ [32,33], and CRF is the capital recovery factor given by Equation (11) [33].

$$
C R F=\frac{i \times(1+i)^{n}}{(1+i)^{n}-1}
$$

where $i$ is the fractional interest rate per year and $n$ is the plant lifetime (25 years) [32,33]. In addition, $P E C_{k}$ is the purchase equipment cost for each system component, as defined in Table A3 (see Appendix A).

After computing each component cost rate, the exergoeconomic balance was considered by solving the matrix balance equation for each component:

$$
\begin{gathered}
\dot{C}_{P, k}=\dot{C}_{F, k}-\dot{C}_{L, k}+\dot{Z}_{k} \\
\sum_{e} \dot{C}_{e, k}+\dot{C}_{w, k}=\sum_{i} \dot{C}_{i, k}+\dot{C}_{q, k}+Z_{k}
\end{gathered}
$$

The cost of each stream was obtained by multiplying the specific cost by its exergy rate, as shown in Equation (14).

$$
\dot{C}_{i}=c_{i} \cdot \dot{E}_{i}
$$


where $\dot{C}_{F, k}$ and $\dot{C}_{P, k}$ are the fuel stream and product stream cost rates, respectively. Additionally, the component exergy destruction cost rate was determined by Equation (15):

$$
\dot{C}_{D, k}=c_{F, k} \cdot \dot{E}_{D, k}
$$

Finally, the exergoeconomic factor is expressed as [33,34]:

$$
f_{k}=\frac{\dot{Z}_{k}}{\dot{Z}_{k}+c_{f, k} \dot{E}_{D, k}}
$$

The exergoeconomic balance equations of the different ISGC system components are presented in Table A4 of Appendix A.

\subsection{Conventional Exergoenvironmental Analysis}

The life cycle assessment (LCA) is an environmental analysis methodology broadly used for products, processes, and services. The LCA can be carried out after technical and economic analyses. In this study, LCA was implemented within the exergoenvironmental analysis. In this way, the exergoenvironmental analysis was performed via three phases: (1) exergy analysis of each process stream; (2) estimation of environmental impacts related to the manufacturing process of each system component; and, finally, (3) the exergoenvironmental formulation was used to estimate the environmental impacts of streams based on the exergy analysis. The exergoenvironmental analysis was carried out via the following equations.

The relationship between exergy and environmental impact for each stream $i$ is provided by Equation (17).

$$
\dot{B}_{i}=b_{i} \dot{E}_{i}
$$

where $\dot{B}_{i}$ is the environmental impact rate (given in pts $/ \mathrm{s}$ ), $b_{i}$ is the exergoenvironmental impact (pts/kJ), and $\dot{E}_{i}$ the stream exergy rate $(\mathrm{kW})$. Similarly to the exergoeconomic analysis, the following balance is required for the exergoenvironmental analysis:

$$
\sum \dot{B}_{i n, k}-\sum \dot{B}_{\text {out }, k}+\dot{Y}_{k}=0
$$

where $\dot{Y}_{k}$ is the $k$-th component environmental impact rate, defined through ECO-Indicator 99 [35]. This parameter is obtained by Equation (19) [36].

$$
\dot{Y}_{k}=b m_{k} \cdot w_{k}
$$

where $b m_{k}$ and $w_{k}$ are the per weight environmental impact (mpts $/ \mathrm{kg}$ ) and the kth component weight (tons), respectively. The latter is given in Table A5 of Appendix A for the different system components.

The environmental impact associated with the exergy destruction of the $k$-th component is written as:

$$
\dot{B}_{D, k}=\dot{E}_{D, k} b_{F, k}
$$
as [37]:

The cumulative environmental impact rate $\left(\dot{B}_{T, k}\right)$ for the $k$-th component is denoted

$$
\dot{B}_{T, k}=\dot{B}_{D, k}+\dot{Y}_{k}
$$

The corresponding balance equations for the environmental impact rate of system components are listed in Table A6 (see Appendix A).

The exergoenvironmental factor shown in Equation (22) is an important criterion that expresses the ratio of the equipment component-related environmental impact to the sum of the component-related and operational-related environmental impact. An 
exergoenvironmental factor value around 1 indicates that the component environmental effects are greater than the operational-related environmental impact.

$$
f_{b, k}=\frac{\dot{Y}_{k}}{\dot{Y}_{k}+b_{f, k} \dot{E} x_{D, k}}
$$

\subsection{Advanced Exergy Analysis}

Advanced exergy analysis can be used to evaluate the exergy destruction sources, thereby leading to potential improvements in the system. In advanced exergy analysis, the equipment irreversibilities are evaluated within two different viewpoints: (1) source of irreversibility and (2) ability to eliminate such irreversibility. From the source perspective, equipment unit irreversibilities are divided into endogenous and exogenous. From the ability to eliminate standpoint, the irreversibility of each system component is categorized as avoidable and unavoidable [38,39]. The former stratification is grounded on theoretical methods, while the latter is calculated grounded on the maximum energy-efficient system commercially available.

\subsubsection{Avoidable and Unavoidable Exergy Destruction}

Unavoidable exergy destruction in system components relates to the limitations imposed by the thermodynamic and physical conditions and technological and economic constraints. In most cases, unavoidable exergy destruction is determined by the authors' knowledge and experience on potentially unavoidable system irreversibilities. The avoidable exergy destruction can be obtained from the unavoidable one by the following equation.

$$
\dot{E}_{D, k}=\dot{E}_{D, k}^{U N}+\dot{E}_{D, k}^{A V}
$$

\subsubsection{Endogenous and Exogenous Exergy Destruction}

Endogenous exergy destruction of system components is associated to the irreversibility of each unit itself. The exogenous exergy destruction is given by the difference between the exergy destruction of the system operating at actual conditions and the endogenous exergy destruction as expressed as follows.

$$
\dot{E}_{D, k}=\dot{E}_{D, k}^{E N}+\dot{E}_{D, k}^{E X}
$$

The engineering approach proposed by Kelly et al. [40] was used in this study, which can be implemented for the equipment that performs chemical reactions, including combustion chambers and gasifiers. Thus, Equation (25) is implemented to obtain endogenous and exogenous exergy destruction.

$$
\dot{E}_{D, t o t}=\dot{E}_{D, k}^{E N}+\dot{E}_{D, k}^{E X}+\dot{E}_{D, o t h e r s}
$$

where $\dot{E}_{D, \text { others }}$ is the summation of the exergy destruction in the system components other than the $k$-th component under analysis.

\section{Results and Discussion}

The results obtained from the conventional and advanced thermodynamics, exergy, exergoeconomic, and exergoenvironmental analyses are presented in the following sections.

\subsection{Validation of Thermodynamic Modelling Results}

This section compares the modelling results for mass flow rate, temperature, and pressure of process streams obtained from MATLAB to those from the simulations performed in Thermoflex software, which are based on real plant data information. The results 
comparison is shown in Table 2. For all streams, the simulated results showed an error lower than $1 \%$, presenting an appropriate agreement with each other.

Table 2. Stream data obtained from simulations in MATLAB and Thermoflex software.

\begin{tabular}{|c|c|c|c|c|c|c|c|c|c|}
\hline \multirow[b]{2}{*}{ Stream } & \multicolumn{3}{|c|}{$\dot{m}[\mathrm{~kg} / \mathrm{s}]$} & \multicolumn{3}{|c|}{$T\left[{ }^{\circ} \mathrm{C}\right]$} & \multicolumn{3}{|c|}{$P[$ bar $]$} \\
\hline & MATLAB & Thermoflex & Error [\%] & MATLAB & Thermoflex & Error [\%] & MATLAB & Thermoflex & Error [\%] \\
\hline 1 & 9.35 & 9.351 & 0 & 25 & 25 & 0 & 40.58 & 40.58 & 0 \\
\hline 2 & 0.14 & 0.14 & 0 & 100 & 100 & 0 & 1.013 & 1.0135 & 0 \\
\hline 3 & 182.1 & 182 & 0.05 & 35 & 35 & 0 & 0.92 & 0.9214 & 0 \\
\hline 4 & 28.11 & 28.11 & 0.01 & 400 & 400 & 0 & 35.61 & 35.61 & 0 \\
\hline 5 & 8.01 & 8.01 & 0 & 142.5 & 142.5 & 0 & 39 & 39 & 0 \\
\hline 6 & 28.53 & 28.53 & 0 & 718.94 & 700 & 2.63 & 37.05 & 37.05 & 0 \\
\hline 7 & 17.4 & 17.4 & 0 & 100 & 100 & 0 & 40 & 40 & 0 \\
\hline 8 & 15.5 & 15.5 & 0 & 25 & 25 & 0 & 37.92 & 37.92 & 0 \\
\hline 9 & 5.16 & 5.16 & 0 & 25 & 25 & 0 & 1.014 & 1.014 & 0 \\
\hline 10 & 28.53 & 28.53 & 0 & 400 & 400 & 0 & 36.32 & 36.32 & 0 \\
\hline 11 & 9.35 & 9.35 & 0 & 250 & 250 & 0 & 39.78 & 39.78 & 0 \\
\hline 12 & 5.16 & 5.16 & 0 & 150 & 150 & 0 & 0.921 & 0.9218 & 0.01 \\
\hline 13 & 110.29 & 110.3 & 0.01 & 353.9 & 353.55 & 0.1 & 0.88 & 0.88 & 0 \\
\hline 14 & 523.2 & 523.2 & 0 & 25 & 25 & 0 & 0.87 & 0.87 & 0 \\
\hline 15 & 110.3 & 110.3 & 0 & 608.9 & 608.9 & 0 & 0.88 & 0.88 & 0 \\
\hline 16 & 28.3 & 28.29 & 0.03 & 473.95 & 474.1 & 0.01 & 24.11 & 24.12 & 0.04 \\
\hline 17 & 0.416 & 0.413 & 0.72 & 400 & 400 & 0 & 1.013 & 1.013 & 0 \\
\hline 18 & 441.19 & 444.2 & 0.002 & 171.42 & 169.6 & 1.06 & 0.87 & 0.87 & 0 \\
\hline 19 & 28.3 & 28.29 & 0.03 & 206.73 & 205.2 & 0.74 & 35.43 & 35.43 & 0 \\
\hline 20 & 551.48 & 551.5 & 0.01 & 608.9 & 608.9 & 0 & 0.88 & 0.88 & 0.01 \\
\hline 21 & 74.351 & 74.35 & 0.01 & 38.74 & 38.74 & 0 & 0.068 & 0.068 & 0 \\
\hline 22 & 74.351 & 74.35 & 0.01 & 38.7 & 38.74 & 0.1 & 0.068 & 0.068 & 0 \\
\hline 23 & 441.19 & 441.2 & 0.01 & 512.47 & 512.9 & 0.08 & 0.88 & 0.88 & 0.01 \\
\hline 24 & 182 & 182 & 0 & 25 & 25 & 0 & 1.013 & 1.013 & 0 \\
\hline 25 & 110.29 & 110.3 & 0.01 & 278.16 & 278.2 & 0.01 & 0.87 & 0.87 & 0 \\
\hline 26 & 33.36 & 33.36 & 0 & 25 & 25 & 0 & 0.87 & 0.87 & 0 \\
\hline 27 & 65 & 65 & 0 & 368.6 & 368.6 & 0 & 39.78 & 39.78 & 0 \\
\hline 28 & 28.29 & 28.29 & 0.02 & 519.05 & 522 & 0.18 & 34.73 & 34.74 & 0.03 \\
\hline 29 & 3238.5 & 3238.5 & 0 & 25 & 25 & 0 & 1.013 & 1.013 & 0 \\
\hline 30 & 441.19 & 441.2 & 0.01 & 346.08 & 344.6 & 0.42 & 0.88 & 0.88 & 0 \\
\hline 31 & 65 & 65 & 0 & 310 & 310 & 0 & 122.4 & 122.4 & 0.01 \\
\hline 32 & 65 & 65 & 0 & 326.19 & 326.2 & 0.01 & 122.4 & 122.4 & 0.01 \\
\hline 33 & 65 & 65 & 0 & 535 & 535 & 0 & 119.95 & 120 & 0.04 \\
\hline 34 & 9.351 & 9.351 & 0 & 250.03 & 250 & 0.01 & 39.78 & 39.78 & 0.01 \\
\hline 35 & 441.19 & 441.2 & 0.01 & 608.9 & 608.9 & 0 & 0.88 & 0.88 & 0.01 \\
\hline 36 & 27.24 & 27.25 & 0.03 & 400 & 400 & 0 & 35.43 & 35.43 & 0 \\
\hline 37 & 0.865 & 0.867 & 0.23 & 400 & 395.1 & 1.22 & 0.87 & 0.87 & 0 \\
\hline 38 & 74.35 & 74.35 & 0.01 & 536.8 & 536.8 & 0 & 38.98 & 39 & 0.05 \\
\hline 39 & 3238.5 & 3238.5 & 0 & 37.08 & 37.08 & 0 & 0.66 & 0.66 & 0.7 \\
\hline 40 & 74.35 & 74.35 & 0.01 & 351.28 & 351.2 & 0.02 & 39.78 & 39.78 & 0 \\
\hline 42 & 65 & 65 & 0 & 25 & 25 & 0 & 124.85 & 124.85 & 0 \\
\hline
\end{tabular}


Table 3 displays the output parameters for the power and heat transfer rates of the different system components obtained from Thermoflex (based on real plant data information) and MATLAB simulations. In all cases, the simulated results presented an error lower than $4.5 \%$ and, therefore, an appropriate agreement with each other.

Table 3. Power and heat transfer rates for different components obtained from simulations in MATLAB and Thermoflex software.

\begin{tabular}{cccc}
\hline Parameter & MATLAB & Thermoflex & Error [\%] \\
\hline$W_{G T \text { Pack }}[\mathrm{MW}]$ & 229.55 & 229.55 & 0.00 \\
\hline$W_{A C}[\mathrm{MW}]$ & 219.66 & 213.55 & 2.78 \\
\hline$W_{G T}[\mathrm{MW}]$ & 458.86 & 444.73 & 3.07 \\
\hline$Q_{S H 1}[\mathrm{MW}]$ & 49.16 & 49.20 & 0.085 \\
\hline$Q_{E V}[\mathrm{MW}]$ & 82.50 & 83.55 & 1.27 \\
\hline$Q_{E C 1}[\mathrm{MW}]$ & 82.69 & 83.34 & 0.78 \\
\hline$Q_{S H 2}[\mathrm{MW}]$ & 32.01 & 32.05 & 0.12 \\
\hline$Q_{E C 2}[\mathrm{MW}]$ & 9.07 & 9.13 & 0.74 \\
\hline$W_{A S U}[\mathrm{MW}]$ & 9.12 & 9.13 & 0.08 \\
\hline$W_{E X P}[\mathrm{~kW}]$ & 2.67 & 2.79 & 4.37 \\
\hline$W_{S T 1}$ & 19.70 & 19.48 & 1.15 \\
\hline$W_{S T 2}$ & 87.30 & 87.04 & 0.29 \\
\hline
\end{tabular}

Table 4 exhibits the main results of the proposed ISGC modelling approach compared to those found by Zhang et al. [29], including the exergy input to the system, exergy destruction, net output power, thermal efficiency, and the ratio of exergy destruction to total input exergy. The results showed a similar thermal efficiency of around $50 \%$ for both studies. Even though the pre-combustion chamber was omitted in the present system (compared to Zhang et al. [29]), the ratio of exergy destruction to total input exergy was decreased by $4.8 \%$ (from $56.7 \%$ to $53.98 \%$ ). Therefore, in the output power scale of the cycle, this configuration also reduced the investment cost. It should be noted that the main goal in the study was to increase exergoeconomic efficiency; therefore, expressing the increase in thermal efficiency from $49.5 \%$ to $50 \%$ indicated that replacing the coal fuel feed with heavy refinery fuel in cycle did not reduce the relative thermal efficiency but also caused a slight improvement. Furthermore, the system produced 319.92 MW of power by feeding on $15.5 \mathrm{~kg} / \mathrm{s}$ of heavy refinery fuel. This occurred at a thermal efficiency of $50.01 \%$ and exergy efficiency of $53.98 \%$.

Table 4. Comparison between the obtained ISGC modelling results with those from Zhang et al. [29].

\begin{tabular}{ccc}
\hline Parameter & Present Study & Zhang et al. [29] \\
\hline Exergy input $(\mathrm{MW})$ & 678.99 & 861.06 \\
\hline Exergy destruction $(\mathrm{MW})$ & 366.57 & 488.81 \\
\hline Net output power $(\mathrm{MW})$ & 319.92 & 389.77 \\
\hline Thermal efficiency $(\%)$ & 50.01 & 49.94 \\
\hline$E X_{D} / E X_{\text {input }}(\%)$ & 53.98 & 56.7 \\
\hline
\end{tabular}

\subsection{Conventional Exergy-Based Analyses}

Table 5 shows the results obtained for the conventional exergy, exergoeconomic, and exergoenvironmental analyses for each process stream through system simulations using MATLAB software environment. 
Table 5. Stream specifications obtained from conventional exergy-based analyses.

\begin{tabular}{|c|c|c|c|c|c|c|c|c|}
\hline Stream & $\dot{m}[\mathrm{~kg} / \mathrm{s}]$ & $T\left[{ }^{\circ} \mathrm{C}\right]$ & $P[$ bar $]$ & $\dot{E x}[\mathrm{MW}]$ & $c[\$ / \mathrm{GJ}]$ & $\dot{C}[\$ / \mathrm{h}]$ & $b[\mathrm{pts} / \mathrm{GJ}]$ & $B$ [pts/h] \\
\hline 1 & 9.35 & 25.00 & 40.58 & 0.037 & 0.000 & 0.000 & 0.00 & 0.000 \\
\hline 2 & 0.14 & 100.00 & 1.013 & 0.000 & 0.000 & 0.000 & 0.00 & 0.000 \\
\hline 3 & 182.1 & 35.00 & 0.92 & 0.000 & 0.000 & 0.000 & 0.00 & 0.000 \\
\hline 4 & 28.11 & 400.00 & 35.61 & 587.25 & 5.21 & $11,027.18$ & 1,600 & $3,382,571.52$ \\
\hline 5 & 8.01 & 142.5 & 39.00 & 3.48 & 140.83 & 1766.34 & 22,200 & $278,361.36$ \\
\hline 6 & 28.53 & 718.94 & 37.05 & 601.89 & 4.94 & $10,721.34$ & 1500 & $3,250,206$ \\
\hline 7 & 17.40 & 100.00 & 40.00 & 0.65 & 0.00 & 0.000 & 0.000 & 0.000 \\
\hline 8 & 15.50 & 25.00 & 37.92 & 678.99 & 2.28 & 5592.70 & 14.00 & $34,221.09$ \\
\hline 9 & 5.16 & 25.00 & 1.014 & 0.000 & 0.00 & 0.00 & 0.000 & 0.000 \\
\hline 10 & 28.53 & 400.00 & 36.32 & 589.38 & 4.94 & 9623.63 & 1500 & $3,182,652$ \\
\hline 11 & 9.35 & 250.00 & 39.78 & 2.40 & 51.50 & 446.31 & 29,400 & $254,756.88$ \\
\hline 12 & 5.16 & 150.00 & 0.921 & 2.58 & 16.92 & 157.28 & 241,400 & $2,243,861.28$ \\
\hline 13 & 110.29 & 353.90 & 0.88 & 12.11 & 9.97 & 434.79 & 3,800 & $165,719.52$ \\
\hline 14 & 523.2 & 25.00 & 0.87 & 0.00 & 0.00 & 0.00 & 0.000 & 0.000 \\
\hline 15 & 110.3 & 608.9 & 0.88 & 30.40 & 9.97 & 1091.26 & 3800 & $415,926.72$ \\
\hline 16 & 28.30 & 473.95 & 24.11 & 589.11 & 5.49 & $11,644.23$ & 1,800 & $3,499,313.4$ \\
\hline 17 & 0.41 & 400.00 & 1.013 & 0.069 & 0.00 & 0.00 & 0.000 & 0.000 \\
\hline 18 & 441.19 & 171.42 & 0.87 & 12.08 & 0.00 & 0.00 & 0.000 & 0.000 \\
\hline 19 & 28.30 & 206.73 & 35.43 & 583.37 & 5.46 & $11,473.02$ & 1700 & $3,570,224.4$ \\
\hline 20 & 551.48 & 608.9 & 0.88 & 152.29 & 9.97 & 5465.99 & 3,800 & $2,083,327.2$ \\
\hline 21 & 74.35 & 38.74 & 0.068 & 7.26 & 11.85 & 309.71 & 12,500 & 326.7 \\
\hline 22 & 74.35 & 38.70 & 0.068 & 0.08 & 11.85 & 3.79 & 12,500 & $4,000.5$ \\
\hline 23 & 441.19 & 512.47 & 0.88 & 91.80 & 9.97 & 3295.06 & 3,800 & $1,255,892.4$ \\
\hline 24 & 182.00 & 25.00 & 1.013 & 0.00 & 0.00 & 0.00 & 0.000 & 0.000 \\
\hline 25 & 110.29 & 278.16 & 0.87 & 7.81 & 0.00 & 0.00 & 0.000 & 0.000 \\
\hline 26 & 33.36 & 25.00 & 0.87 & 0.00 & 0.00 & 0.00 & 0.000 & 0.000 \\
\hline 27 & 65.00 & 368.6 & 39.78 & 75.30 & 13.06 & 3542.75 & 12,500 & $3,388,770$ \\
\hline 28 & 28.29 & 519.05 & 34.73 & 592.29 & 5.49 & $11,706.01$ & 1800 & $3,838,039.2$ \\
\hline 29 & $3,238.5$ & 25.00 & 1.013 & 0.043 & 0.00 & 0.00 & 0.000 & 0.000 \\
\hline 30 & 441.19 & 346.08 & 0.88 & 46.65 & 9.97 & 1674.46 & 3,800 & $638,213.04$ \\
\hline 31 & 65.00 & 310.00 & 122.40 & 26.48 & 18.00 & 1721.94 & 14,800 & $1,411,120.8$ \\
\hline 32 & 65.00 & 326.19 & 122.40 & 68.32 & 13.78 & 3390.84 & 12,300 & $3,025,342.44$ \\
\hline 33 & 65.00 & 535.00 & 119.95 & 96.02 & 13.08 & 4523.55 & 12,500 & $4,320,990$ \\
\hline 34 & 9.35 & 250.03 & 39.78 & 9.30 & 6.312 & 211.46 & 11,800 & $395,318.88$ \\
\hline 35 & 441.19 & 608.9 & 0.88 & 121.83 & 9.970 & 4372.72 & 3800 & $1,666,634.4$ \\
\hline 36 & 27.24 & 400.00 & 35.43 & 587.09 & 5.427 & $11,470.07$ & 1600 & $3,381,638.4$ \\
\hline 37 & 0.86 & 400.00 & 0.87 & 0.127 & 0.000 & 0.00 & 0.000 & 0.000 \\
\hline 38 & 74.35 & 536.8 & 38.98 & 103.02 & 11.85 & 4394.83 & 12,500 & $4,635,900$ \\
\hline 39 & $3,238.5$ & 37.08 & 0.66 & 3.156 & 27.20 & 309.08 & 32,100 & $364,707.36$ \\
\hline 40 & 74.35 & 351.28 & 39.78 & 84.46 & 6.98 & 2124.84 & 7100 & $2,158,899.84$ \\
\hline 41 & 65.00 & 25.00 & 124.85 & 0.805 & 0.00 & 0.00 & 0.000 & 0.000 \\
\hline
\end{tabular}


Table 6 displays the exergy, exergoeconomic, and exergoenvironmental analyses' results for each equipment piece in the cycle. The results show that the exergy efficiency of the solar field and the condenser was approximately $20 \%$ and $43 \%$, respectively. One reason for such exergy efficiency values is the relatively low efficiency in the air separation unit $(38 \%)$. The latter value was owed to using a membrane-based oxygen separation system, which required high-power-consuming compressors.

Table 6. Results obtained from conventional exergy, exergoeconomic, and exergoenvironmental analyses for the different system components.

\begin{tabular}{|c|c|c|c|c|c|c|c|c|c|}
\hline Equipment & $\dot{Z}[\$ / h]$ & $f[\%]$ & $r[\%]$ & $\dot{C}_{D}[U S \$ /$ & $\dot{Y}[p t s / h]$ & $f b[\%]$ & $r b[\%]$ & $\dot{B}_{D}[p t s / \mathrm{h}]$ & $\varepsilon[\%]$ \\
\hline ASU & $1,341.72$ & 83.66 & 991.04 & 262.08 & 415.08 & 0.48 & 162.71 & $87,654.6$ & 38.18 \\
\hline Solar field & 157.32 & 100 & - & 0 & 1190.52 & 100 & - & 0 & 20.09 \\
\hline Gasifier & 340.92 & 81.26 & 62.35 & 786.6 & $11,100.24$ & 3.98 & 12.17 & $267,465.6$ & 89.54 \\
\hline Syngas cooler & 6.84 & 7.76 & 72.09 & 81.72 & 211.68 & 00.83 & 67.05 & 25,318 & 60.06 \\
\hline Heat exchanger & 9.36 & 12.7 & 46.16 & 64.08 & 110.16 & 00.55 & 40.53 & $19,833.4$ & 71.28 \\
\hline $\mathrm{H}_{2} \mathrm{~S}$ remover & 529.2 & 93.53 & 5.41 & 36.72 & 59.76 & 0.53 & 00.35 & 11,345 & 99.65 \\
\hline $\mathrm{CO}_{2}$ capture & 445.68 & 83.55 & 150.04 & 87.84 & 59.76 & 0.32 & 24.46 & $18,383.4$ & 80.2 \\
\hline Humidifier & 3.96 & 5.16 & 0.68 & 73.44 & 57.96 & 0.26 & 00.65 & $21,995.2$ & 99.36 \\
\hline Expander & 35.28 & 77.95 & 85.37 & 10.08 & $11,642.4$ & 78.41 & 87.17 & 3205.8 & 84.16 \\
\hline Combustion chamber & 5.4 & 0.12 & 25.23 & 4550.4 & 7364.16 & 0.46 & 25.32 & $1,603,906.9$ & 79.87 \\
\hline Air compressor & 756.36 & 44.88 & 18.17 & 929.16 & 1319.04 & 0.42 & 10.06 & 310,375 & 90.9 \\
\hline Gas turbine & 4174.92 & 86.05 & 29.46 & 677.16 & 9908.28 & 3.74 & 4.27 & 255,060 & 96.05 \\
\hline Superheater (1) & 48.96 & 0.09 & 13.31 & 83.52 & $13,113.36$ & 29.42 & 11.9 & $31,462.9$ & 99.25 \\
\hline Evaporator & 28.87 & 36.88 & 11.14 & 118.8 & 644.76 & 1.42 & 8.03 & 44,807 & 92.66 \\
\hline Economizer (1) & 47.52 & 9.92 & 38.45 & 430.92 & 499.32 & 0.31 & 34.74 & $162,280.8$ & 74.28 \\
\hline Superheater (2) & 23.04 & 2.53 & 39.15 & 888.12 & 9027.72 & 1.25 & 38.64 & 710,712 & 72.38 \\
\hline Economizer (2) & 11.52 & 5.65 & 86.02 & 194.76 & 58.68 & 0.079 & 81.24 & $73,389.6$ & 55.2 \\
\hline Steam turbine (1) & 71.64 & 60.22 & 12.85 & 47.52 & $13,113.36$ & 4.81 & 5.37 & 45,468 & 95.14 \\
\hline Steam turbine (2) & 180.72 & 33.36 & 14.54 & 360.72 & 6807.96 & 1.75 & 9.86 & 381,528 & 91.17 \\
\hline Condenser & 3.19 & 1.81 & 132.81 & 173.16 & 26.28 & 1.81 & 130.42 & 183,060 & 43.4 \\
\hline
\end{tabular}

ASU: air separation unit.

In addition, the results revealed that the combustion chamber had the highest exergy destruction cost. The combustion chamber also presented higher cost and environmental impacts of the exergy destruction when compared to other equipment units. Therefore, its performance should be improved to mitigate its exergy destruction. Heat recovery equipment had the lowest exergoenvironmental coefficient, which indicated that the exergy destruction of this equipment had high adverse effects on the environment. This is affected by thermodynamic factors and other reasons, for instance, the equipment weight, which means that it should be optimally designed from thermodynamic and structure to prevent adverse environmental effects. A practical suggestion to reduce these effects in the heat recovery equipment could be to couple them to a solar energy field to increase the temperature of the water entering the system. In the investment cost section, the highest amount was related to the gas turbines, and the lowest was presented by the condenser.

To better understand the critical parameters of the system, the share of exergy destruction in the system components is depicted in Figure 2. Hence, the combustion chamber, the gasifier, and the HRSG unit had the highest share of exergy destruction. The rate of exergy destruction in the combustion chamber was $43 \%$, which can be reduced by implementing 
an optimal design approach. Compared to other similar cycles, a noteworthy point in the present system is the relatively low exergy destruction share of the gasifier (25\%), which was due to the employment of the air separation unit and, thereby, the injection of pure oxygen.

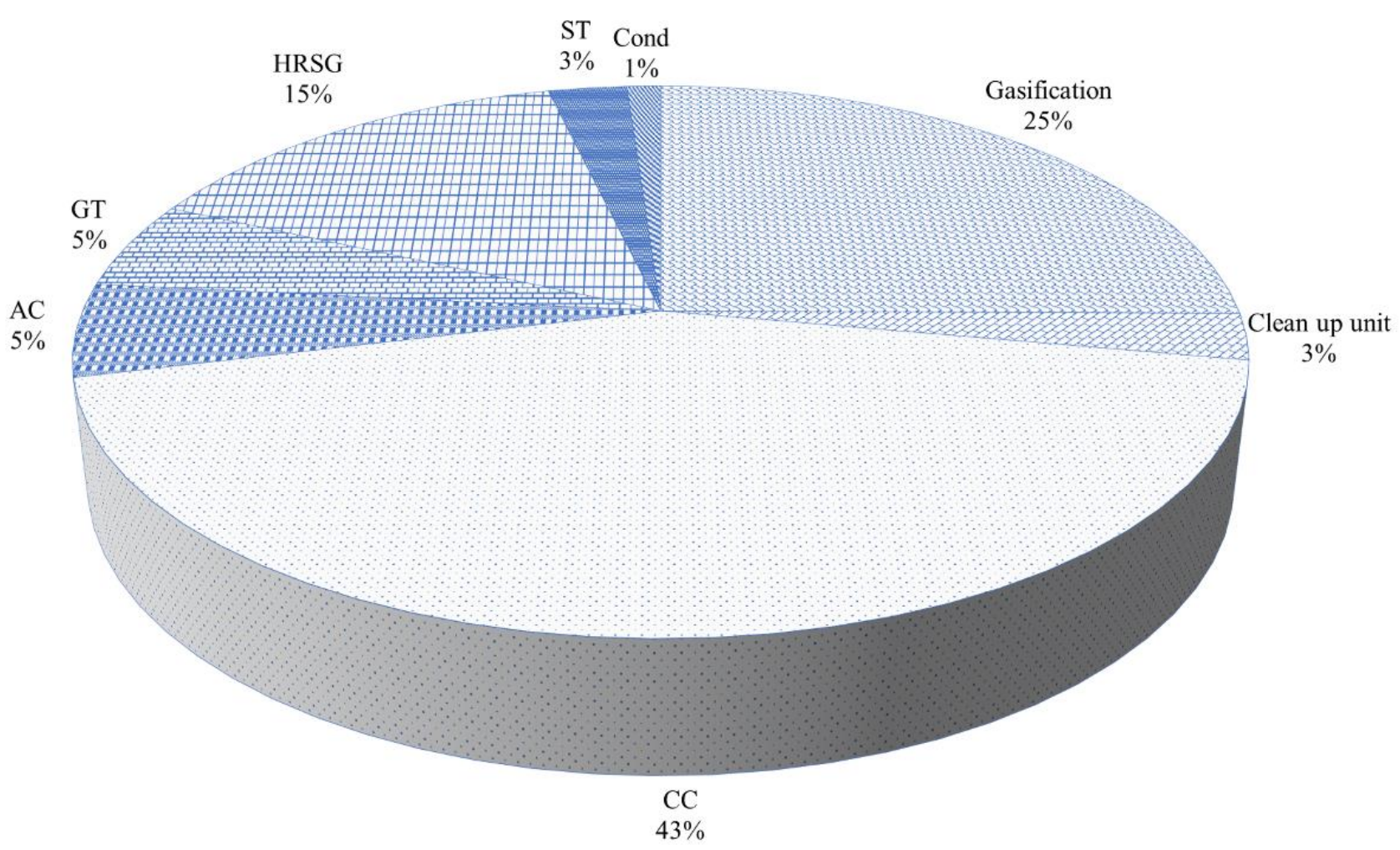

Figure 2. Share of exergy destruction for the different ISGC system components. AC: Air compressor; Cond: Condenser; CC: Combustion chamber; GT: Gas turbine; HRSG: heat recovery steam generator; ST: steam turbine.

Figure 3 displays the cost flow diagram of the proposed system. As observed, the amount of exergoeconomic destruction of the combustion chamber, HRSG, and gasifier was higher than other equipment. Moreover, in terms of equipment cost rate, the highest cost was related to the gasifier, followed by the gas turbine. The remarkable point in this figure that distinguishes this system from other conventional cycles is that the total exergy destruction costs were lower than the total equipment costs. This is owed to the inexpensiveness of the fuel employed in this system, which was a direct function of the exergoeconomic destruction of the equipment.

The total cost of exergy destruction was equal to $164.27 \mathrm{US} \$ / \mathrm{min}$, whereby the highest rate was related to the combustion chamber with $46.17 \%$ share, followed by the HRSG with $17.41 \%$. Besides, in the equipment cost rate section, out of the total $188.52 \$ / \mathrm{min}$, the highest, with $43.46 \%$, was related to the gasifier, followed by the purifying section at $9.05 \%$. The sum of these costs caused the rate of total cycle exergy destruction at $446.02 \$ / \mathrm{min}$.

The system environmental impacts, including the environmental impact rate of the equipment, exergy destruction, and the fuel entering the cycle, are displayed in Figure 4. The summation of these effects led to the total environmental impact rate of the system. As observed in this figure, the environmental impact rate of exergy destruction of the combustion chamber, HRSG, and the gasifier was higher when compared to other equipment pieces in the system. It is noteworthy that the total environmental impact rate of exergy destruction of each piece of equipment was less than the environmental impact rates of the equipment. The reason behind this is the high calorific value of the fuel used in this system, which was a direct function of the exergoenvironmental exergy destruction of the equipment. 

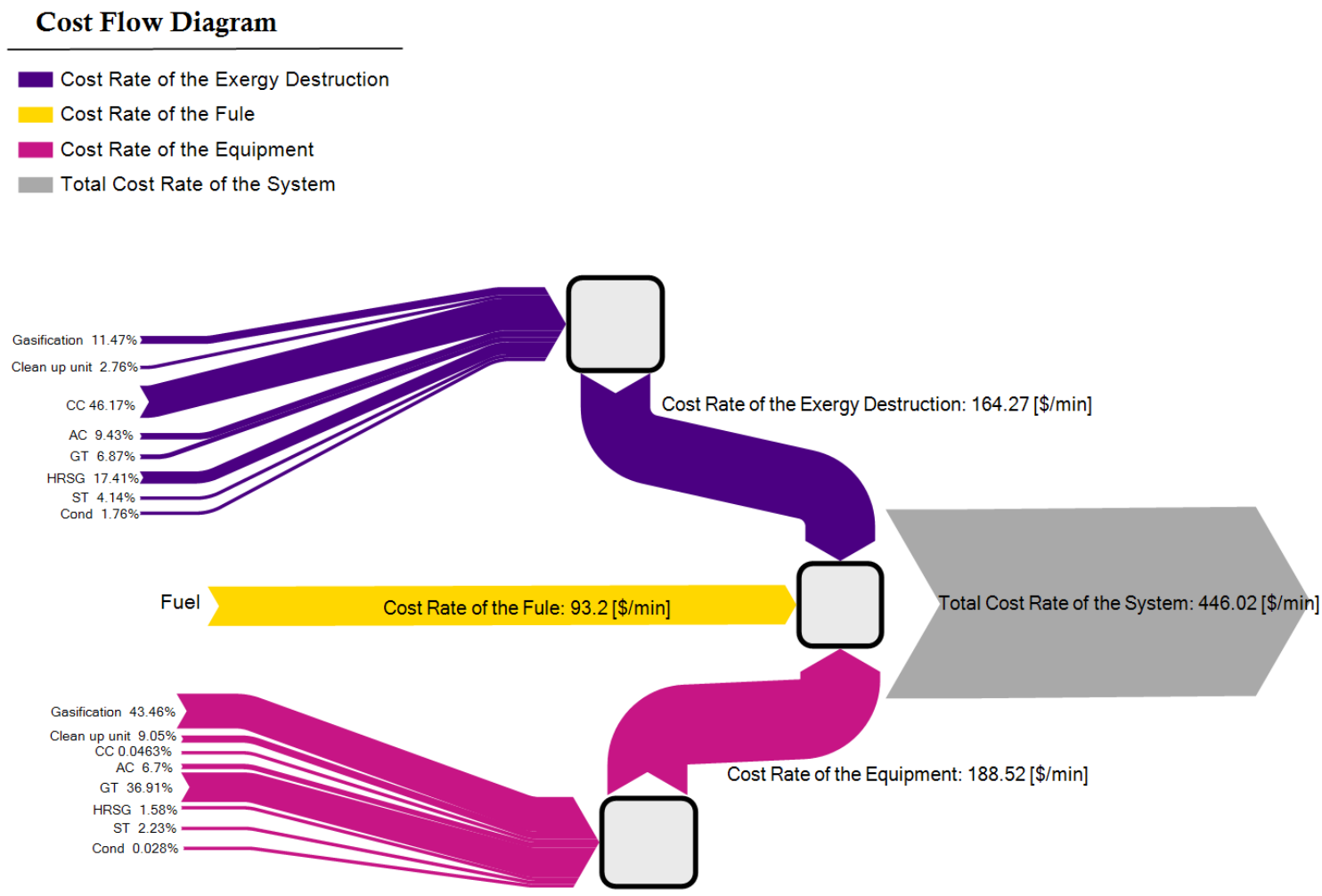

Figure 3. Cost flow diagram of the proposed integrated solar-gasification cycle (ISGC) system. AC: Air compressor; Cond: Condenser; CC: Combustion chamber; GT: Gas turbine; HRSG: heat recovery steam generator; ST: steam turbine.

\section{Environmental Impact Flow Diagram}

\footnotetext{
Environmental Impact Rate of the Exergy Destruction

Environmental Impact Rate of the Fule

Environmental Impact Rate of the Equipment

Total Environmental Impact Rate of the System
}

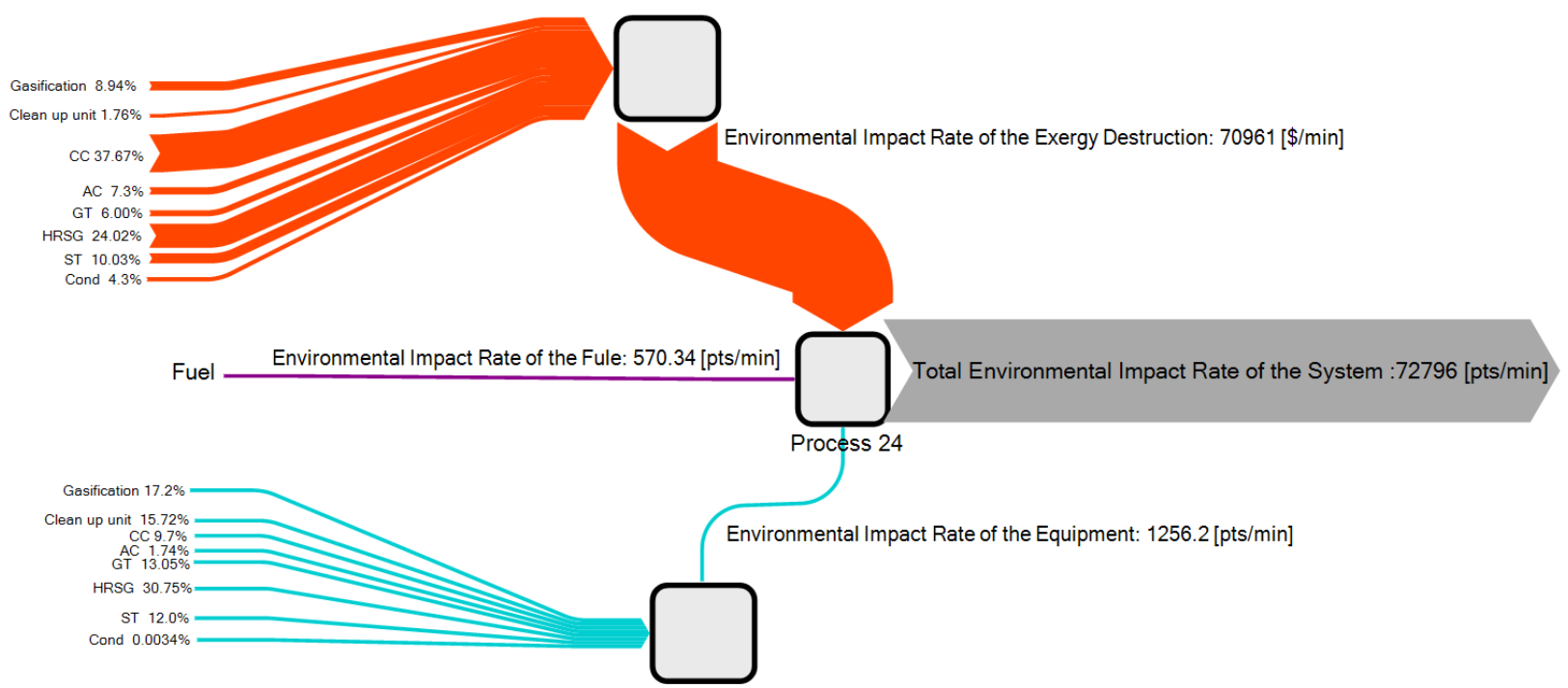

Figure 4. Environmental impact flow diagram of the proposed integrated solar-gasification cycle (ISGC) system. AC: Air compressor; CC: Combustion chamber; Cond: Condenser; GT: Gas turbine; HRSG: heat recovery steam generator; ST: steam turbine. 
The total rate of environmental exergy destruction effects was 70,961 pts / min, in which the highest rate was related to the combustion chamber, with a $37.67 \%$ share, followed by the HRSG unit, with $24.02 \%$. The total equipment environmental impact rate amounted to $22.2 \mathrm{pts} / \mathrm{min}$, among which the HRSG had the highest cost rate, with a $30.75 \%$ share, followed by the gasifier, with $17.2 \%$. The sum of these environmental effects led to the total cycle environmental impact rate of 72,796 pts/min.

\subsection{Advanced Exergy-Dased Analyses}

Figure 5 displays the advanced exergy analysis, namely, avoidable, unavoidable, endogenous, and exogenous exergy destruction in each system equipment. The highest avoidable exergy destruction was related to the condenser, followed by the syngas cooler and the gas turbine. Moreover, the highest endogenous exergy destruction was associated with the solar field, followed by the combustion chamber and the $\mathrm{CO}_{2}$ capture unit. To increase the exergy efficiency, system components with high avoidable exergy destruction such as the condenser, syngas heat exchanger, and gas turbine can be prioritized for modifications. Based on avoidable exergy destruction, the steam turbines 1 and 2, air compressor, and $\mathrm{CO}_{2}$ capture unit had the minimum potential for improvement. Hence, these components do not require any modifications or improvement. In addition, steam turbines 1 and 2 and condenser had minimum endogenous exergy destruction.

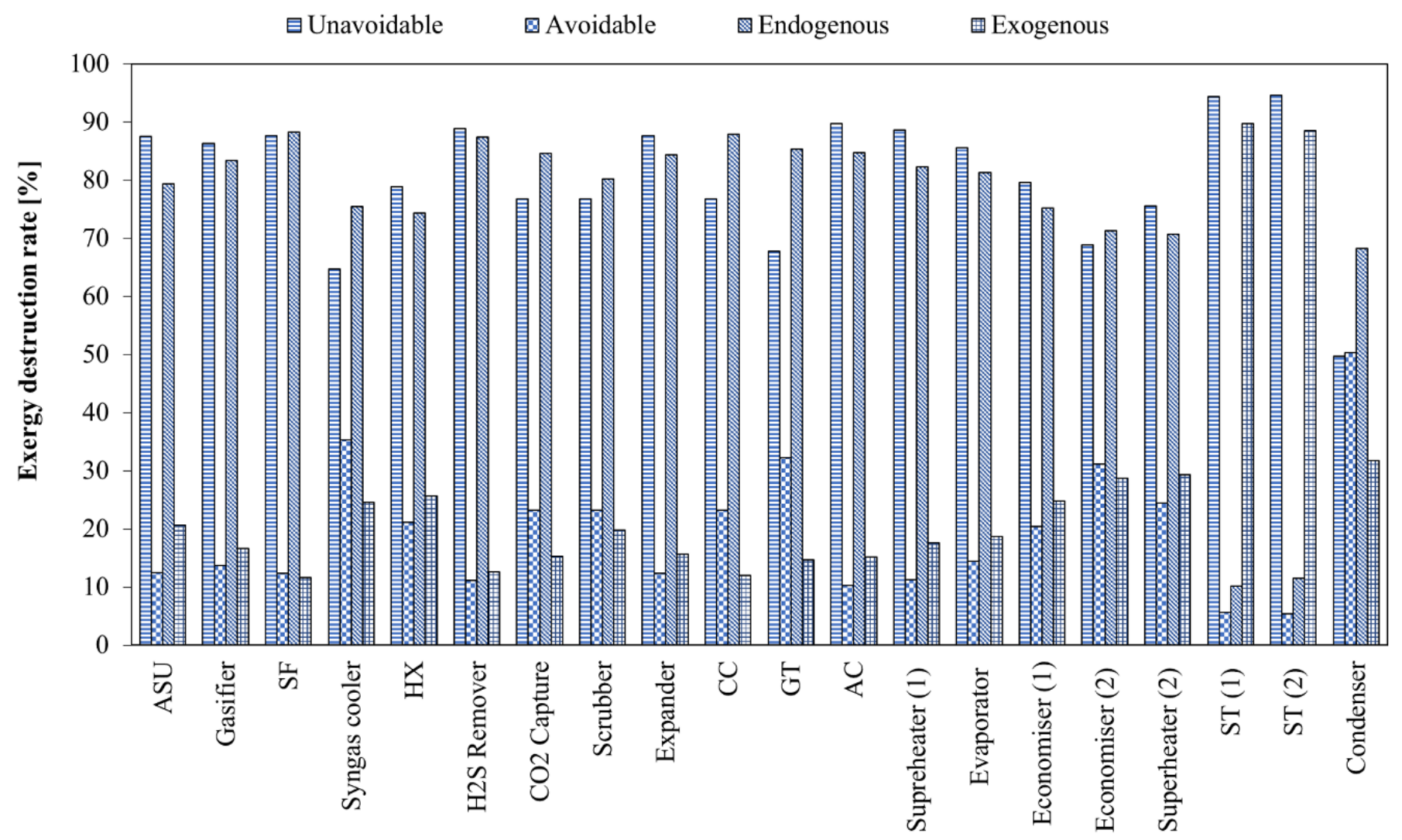

Figure 5. Advanced exergy analysis results obtained for the proposed integrated solar-gasification cycle (ISGC) system. ASU: Air separation unit; CC: Combustion chamber; GT: Gas turbine; HX: heat exchanger; SF: Solar field; ST: Steam turbine.

Figure 6 depicts the advanced exergoeconomic destruction share of each system equipment. As shown, the condenser also had the highest avoidable exergoeconomic destruction share, while the steam turbines had the lowest. Therefore, components with high avoidable exergy destruction such as the condenser can be prioritized for modification to increase the exergoeconomic efficiency. This modification can include changing the type of equipment used, regardless of the cost of exergy destruction. In addition, the syngas 
cooler, gas turbine, economizer, scrubber, and $\mathrm{CO}_{2}$ capture are in the following priority for improvement. However, steam turbines 1 and 2 presented minimum potential for improvement based on the avoidable parameter. Based on the endogenous parts of the cost of exergy destruction, the combustion chamber, gas turbine, air separation unit, $\mathrm{H}_{2} \mathrm{~S}$ removal, and $\mathrm{CO}_{2}$ capture had the highest rates.

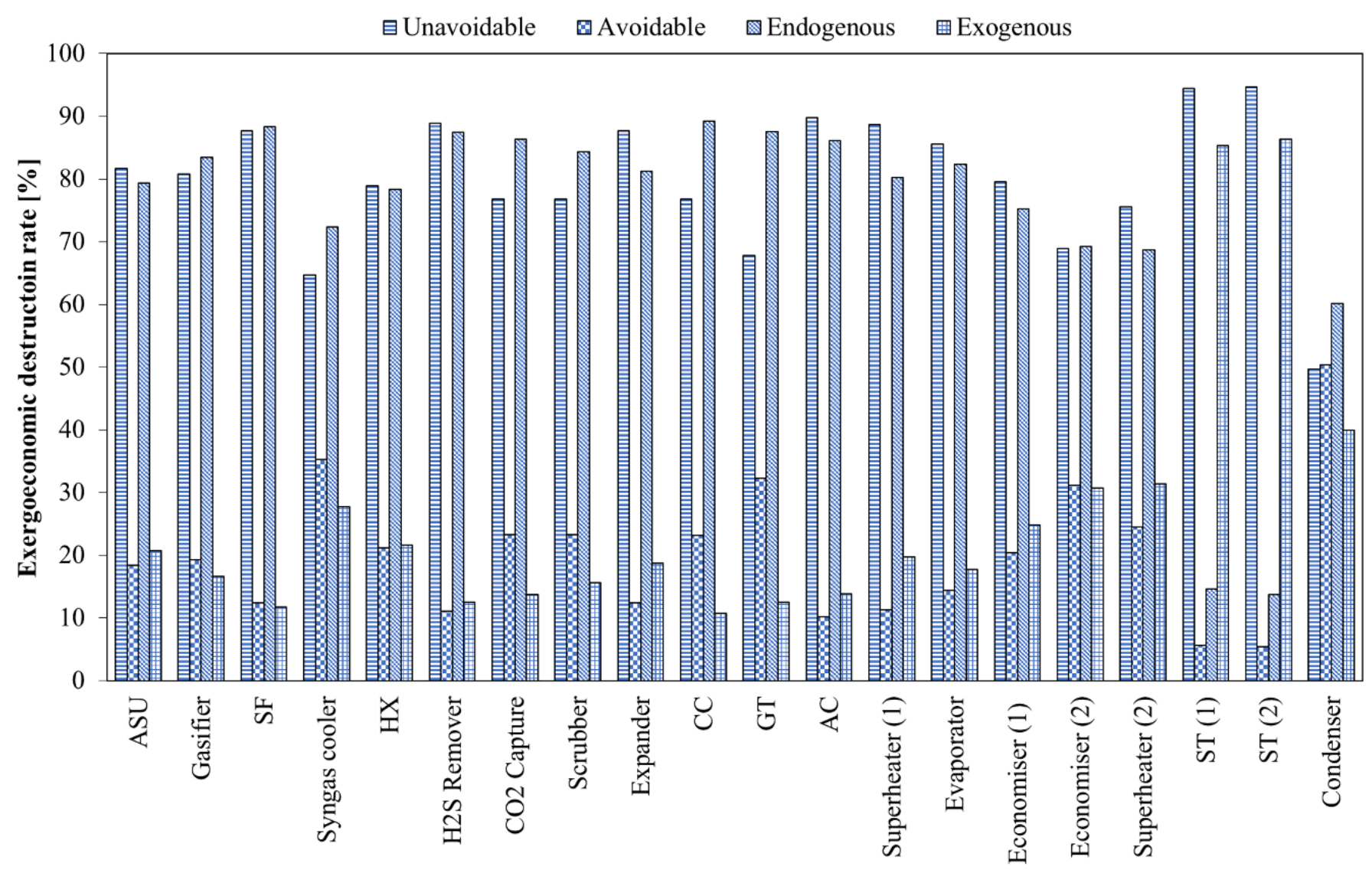

Figure 6. Advanced exergoeconomic analysis results obtained for the proposed integrated solar-gasification cycle (ISGC) system. ASU: Air separation unit; CC: Combustion chamber; GT: Gas turbine; HX: heat exchanger; SF: Solar field; ST: Steam turbine.

The advanced exergoenvironmental destruction share of equipment is shown in Figure 7. Similarly to the previous results, the condenser had the highest avoidable exergoenvironmental destruction share among the equipment units. Moreover, it is noticeable that the components unavoidable exergoenvironmental destruction share in all equipment was higher than avoidable (except for the condenser). In addition, components with high avoidable exergy destruction such as the condenser, syngas cooler, Economizer 2, and GT can be prioritized for modification to increase the exergoenvironmental efficiency. In this case, this modification can be grounded on the type of equipment used in terms of manufacturing processes and lower weight.

Table 7 presents the ranking of the impact of exergy, exergoeconomic, and exergoenvironmental destruction rate parameters in the conventional and advanced analyses for each equipment used in the ISGC system. This table helps determine the distribution and extent of the maximum exergy destructions and identify the effects in the cost and environmental sections to minimize the exergy losses in the optimization step in terms of the least amount of time and cost.

As shown in the conventional results in Table 7, the highest exergy destruction was related to the $\mathrm{CO}_{2}$ capture unit, while the lowest rate was associated with the syngas cooler 
and combustion chamber, simultaneously. Regarding the exergoeconomic destruction rate, the highest value was associated with the solar field $(20 \mathrm{MW})$ and the lowest with the combustion chamber (1 MW). For the sum of exergoeconomic destruction and investment cost, the highest amount was related to the expander (20 MW), whereas the lowest one was to the gas turbine $(1 \mathrm{MW})$. For exergoenvironmental impact rate, the solar field had the highest value $(20 \mathrm{MW})$, while the combustion chamber (1 MW) presented the lowest. Finally, for the sum of component and operational exergoenvironmental impact rate, the highest and lowest values were pertinent to the combustion chamber and solar field, respectively. The highest and lowest values herein indicate the strengths and weaknesses of the present cycle that can be used for optimization and future work, where equipment pieces with lower exergy efficiency can be the focal point for future optimization analysis.

In the advanced analysis section, the highest amount of avoidable exergy destruction was associated with the steam turbine $2(20 \mathrm{MW})$, while the lowest was attributed to the condenser $(1 \mathrm{MW})$. The steam turbine 1 (20 MW) had the highest endogenous exergy destruction, whereas the solar energy field showed the lowest one. In addition, the highest rate of endogenous exergoeconomic destruction was related to the steam turbine $2(20 \mathrm{MW})$, whereas the combustion chamber $(1 \mathrm{MW})$ presented the lowest rate. The highest avoidable exergoenvironmental impact rate was related to the steam turbine $2(20 \mathrm{MW})$, while the lowest was associated with the condenser $(1 \mathrm{MW})$. Finally, the highest rate of endogenous exergoenvironmental impact rate was related to the steam turbine $2(20 \mathrm{MW})$, whereas the lowest one was to the combustion chamber.

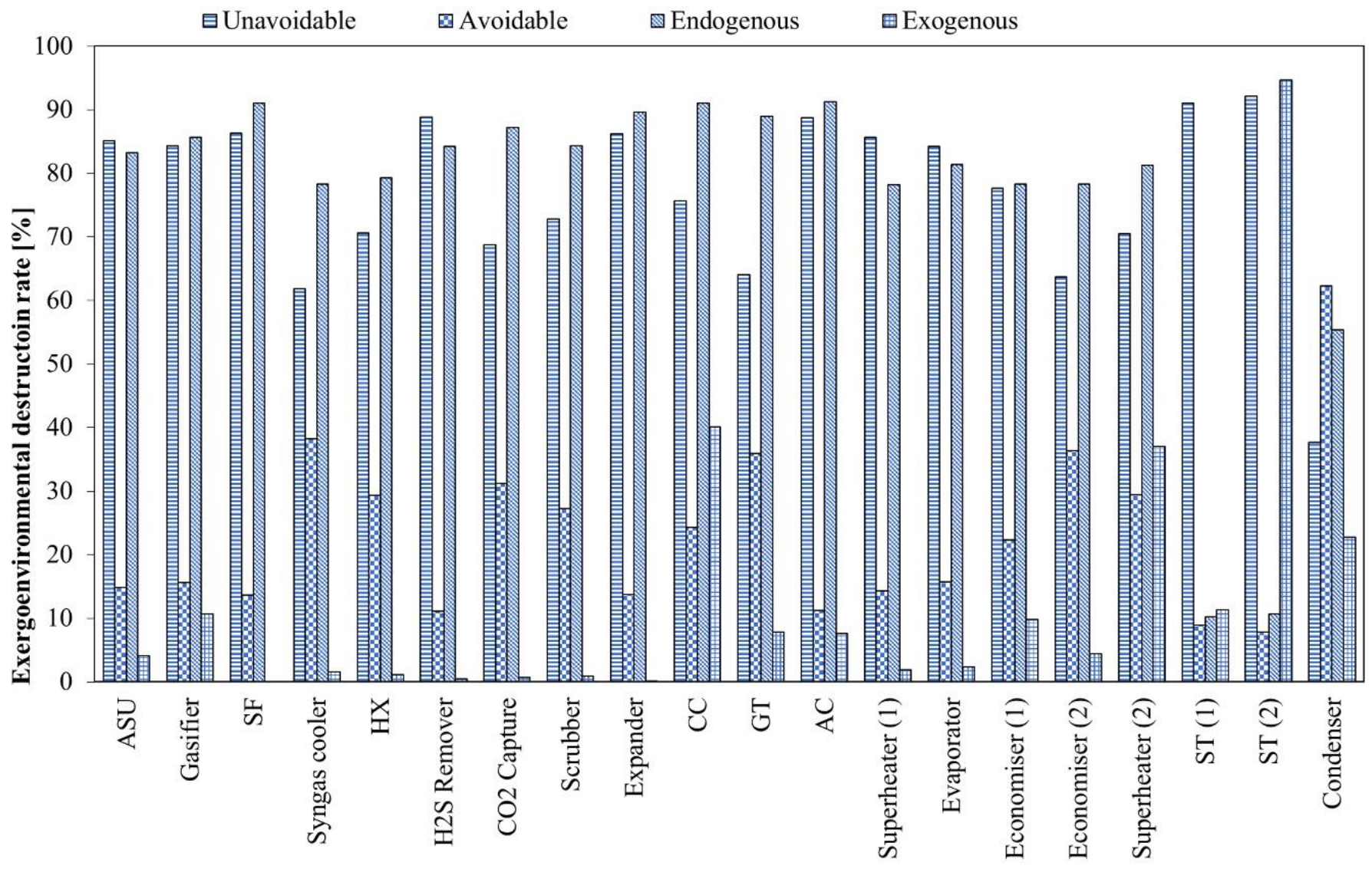

Figure 7. Advanced exergoenvironmental analysis results obtained for the proposed integrated solar-gasification cycle (ISGC) system. ASU: Air separation unit; CC: Combustion chamber; GT: Gas turbine; HX: heat exchanger; SF: Solar field; ST: Steam turbine. 
Table 7. Ranking of equipment obtained from conventional and advanced exergy analyses.

\begin{tabular}{|c|c|c|c|c|c|c|c|c|c|c|}
\hline \multirow[b]{2}{*}{ Equipment } & \multicolumn{5}{|c|}{ Conventional (MW) } & \multicolumn{5}{|c|}{ Advanced (MW) } \\
\hline & $\dot{E}_{D, k}$ & $\dot{C}_{D, k}$ & $\dot{C}_{D, k}+\dot{Z}_{k}$ & $\dot{B}_{D, k}$ & $\dot{B}_{T, k}$ & $\dot{E}_{D, k}^{A V}$ & $\dot{E}_{D, k}^{E N}$ & $\dot{C}_{D, k}^{E N}$ & $\dot{B}_{D, k}^{A V}$ & $\dot{B}_{D, k}^{E N}$ \\
\hline Air separation unit & 9 & 8 & 5 & 9 & 9 & 13 & 12 & 12 & 14 & 12 \\
\hline Solar field & 6 & 20 & 14 & 20 & 20 & 15 & 1 & 2 & 15 & 2 \\
\hline Gasifier & 2 & 4 & 3 & 5 & 5 & 12 & 8 & 8 & 11 & 7 \\
\hline Syngas cooler & 1 & 13 & 17 & 14 & 14 & 2 & 13 & 15 & 2 & 15 \\
\hline Heat exchanger & 13 & 15 & 19 & 16 & 16 & 9 & 14 & 13 & 9 & 13 \\
\hline $\mathrm{H}_{2} \mathrm{~S}$ remover & 16 & 17 & 7 & 18 & 19 & 17 & 6 & 3 & 16 & 3 \\
\hline $\mathrm{CO}_{2}$ capture & 20 & 12 & 9 & 17 & 17 & 17 & 3 & 5 & 8 & 4 \\
\hline Humidifier & 12 & 15 & 18 & 15 & 15 & 6 & 11 & 7 & 7 & 9 \\
\hline Expander & 19 & 19 & 20 & 19 & 18 & 14 & 5 & 10 & 13 & 10 \\
\hline Combustion chamber & 1 & 1 & 2 & 1 & 1 & 8 & 2 & 1 & 6 & 1 \\
\hline Air compressor & 4 & 2 & 4 & 4 & 4 & 18 & 7 & 6 & 18 & 6 \\
\hline Gas turbine & 5 & 5 & 1 & 6 & 6 & 3 & 4 & 4 & 3 & 5 \\
\hline Superheater (1) & 15 & 13 & 15 & 13 & 13 & 16 & 9 & 11 & 17 & 11 \\
\hline Evaporator & 14 & 11 & 13 & 12 & 12 & 11 & 10 & 9 & 12 & 8 \\
\hline Economizer (1) & 7 & 6 & 10 & 8 & 8 & 10 & 15 & 14 & 10 & 14 \\
\hline Superheater (2) & 3 & 3 & 6 & 2 & 2 & 5 & 17 & 17 & 5 & 17 \\
\hline Economizer (2) & 17 & 9 & 11 & 10 & 10 & 4 & 16 & 16 & 4 & 16 \\
\hline Steam turbine (1) & 18 & 18 & 16 & 11 & 11 & 19 & 20 & 19 & 19 & 19 \\
\hline Steam turbine (2) & 8 & 7 & 8 & 3 & 3 & 20 & 19 & 20 & 20 & 20 \\
\hline Condenser & 11 & 10 & 12 & 7 & 7 & 1 & 18 & 18 & 1 & 18 \\
\hline
\end{tabular}

\section{Conclusions}

This paper investigates a new integrated solar-assisted gasification cycle (ISGC) for producing steam and power utilities from low-cost heavy refinery fuels while enhancing energy efficiency and economic and environmental performance indicators. In the proposed ISGC system, syngas from the gasifier enters the turbine to produce power after purification and separation of pollutants. Then, it is sent to the steam section for thermal energy recovery. In addition, a solar energy field and a two-pressure heat recovery steam generator (HRSG) are integrated into the plant to enhance the overall economic and environmental plant viability. In this new study, the ISGC system was modelled in MATLAB software, and the results were validated using Thermoflex software. Conventional and advanced energy, exergy, exergy-economic, and exergy-environmental (4E) analyses were implemented to evaluate the economic and environmental system performance. In addition, the $4 \mathrm{E}$ analyses allowed for the detailed examination of the different system units and the determination of a prioritization order for future optimization and improvement.

The results obtained from the $4 \mathrm{E}$ analyses revealed that replacing the coal fuel feed with heavy refinery fuel allows for a slight improvement in the thermal efficiency, from $49.5 \%$ to $50 \%$. Moreover, the ratio of exergy destruction to total input exergy was decreased by $4.8 \%$ compared to results for the conventional cycle in the literature. The latter result indicated that the proposed ISGC configuration can also reduce the plant investment cost. Besides, the system produced $319.92 \mathrm{MW}$ of power by feeding on $15.5 \mathrm{~kg} / \mathrm{s}$ of heavy refinery fuel, at a thermal efficiency of $50.01 \%$ and exergy efficiency of $53.98 \%$. The results also showed an investment cost of $\$ 466$ million, gauged at a system cost rate of $446 \$ / \mathrm{min}$ and an environmental impact rate of $72,796 \mathrm{pts} / \mathrm{min}$. To sum up, these results demonstrate 
that the proposed ISGC is theoretically viable for converting heavy refinery fuels into syngas and producing power. Therefore, the new approach provides a feasible solution towards reducing environmental impacts related to heavy refinery fuels, particularly for oil-rich countries with high availability of solar resources.

The thermodynamic simulation results show that the computer code developed in MATLAB has high accuracy compared with the Thermoflex software (with overall errors lower than $4.5 \%$ ). This verification of results is acceptable for steady-state conditions, and high-accuracy is achieved. However, for dynamic and transient analyses, these assumptions are not enough. In this case, the kinetic model must be considered for the gasifier. Additionally, part-load conditions for turbines and compressors should be implemented.

Some recommendations for future research include adding a set of solar collectors to the entrance of the HRSG unit for preheating the inlet water, which could further improve energy efficiency; using pure oxygen produced in the high-pressure air separation unit to feed the combustion chamber (instead of atmospheric air) while eliminating the air compressor since this alternative could lead to higher combustion efficiency and a decrease in investment costs; using different carbon capture technologies; optimizing main design and operating parameters; using a gasifier system with higher temperature and pressure tolerance; and, finally, comprehensive footprint assessment can be performed for improving environmental analysis of a proposed system.

Author Contributions: Conceptualization, M.H.K.M.; methodology, E.J. and M.H.K.M.; software and computer code development, E.J. and M.H.K.M.; validation, E.J.; formal analysis, E.J., M.H.K.M., M.D. and V.C.O.; investigation, E.J., M.H.K.M. and M.D.; resources, M.H.K.M.; data curation, E.J.; writing — original draft preparation, M.D.; writing—review and editing, V.C.O.; visualization, V.C.O.; supervision, M.H.K.M.; project administration, V.C.O.; funding acquisition, V.C.O. All authors have read and agreed to the published version of the manuscript.

Funding: This research received no external funding.

Institutional Review Board Statement: Not applicable.

Informed Consent Statement: Not applicable.

Data Availability Statement: Not applicable.

Conflicts of Interest: The authors declare no conflict of interest.

\section{Nomenclature}

$\begin{array}{ll}\text { A } & \text { area } \\ \text { AC } & \text { air compressor } \\ \text { ASU } & \text { Air separation unit } \\ b_{i} & \text { exergoenvironmental impact } \\ \text { B } & \text { environmental impact } \\ \dot{B} & \text { environmental coefficient } \\ \text { bm } & \text { environmental coefficient (per mass) } \\ \text { C } & \text { exergy destruction cost rate } \\ \text { CC } & \text { combustion chamber } \\ \text { CCHP } & \text { combined cooling heat and power } \\ \text { CHP } & \text { combined heat and power } \\ \dot{C} & \text { cost rate } \\ \text { COND } & \text { condenser } \\ \text { Cp } & \text { specific heat capacity } \\ \text { CRF } & \text { capital recovery factor } \\ \dot{E} & \text { exergy rate } \\ \text { Er } & \text { expansion ratio } \\ \text { Ex } & \text { specific exergy }\end{array}$




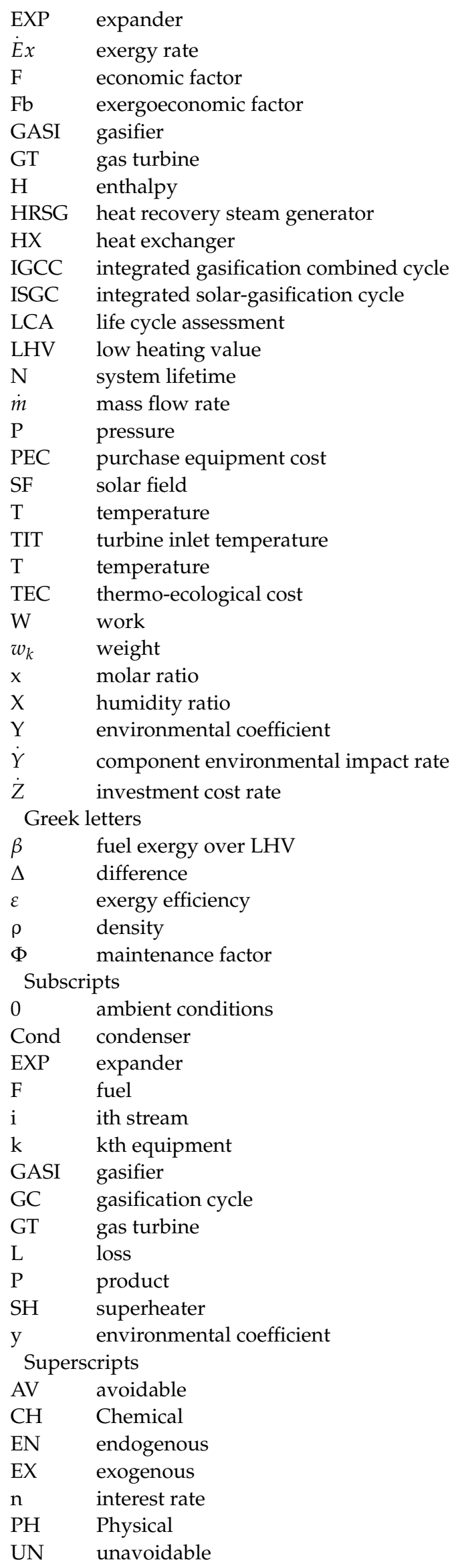




\section{Appendix A}

Table A1. Thermodynamic relations: process operating conditions and unknown parameters used for modelling the different ISGC system components.

\begin{tabular}{|c|c|c|c|}
\hline Comp. & Relations & Process Conditions & $\begin{array}{l}\text { Unknown } \\
\text { Parameters }\end{array}$ \\
\hline 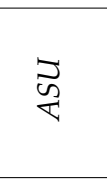 & $\begin{array}{l}W_{A S U-a i r}=\dot{m}_{\text {air }}\left(h_{\text {out }}-h_{\text {in }}\right) \\
h_{\text {out }}=h_{\text {in }}+v_{\text {in }}\left(P_{\text {out }}-P_{\text {in }}\right) \\
W_{A S U, O_{2}}=\dot{m}_{O_{2}}\left(h_{\text {out }}-h_{\text {in }}\right) \\
h_{\text {out }}=h_{\text {in }}+v_{\text {in }}\left(P_{\text {out }}-P_{\text {in }}\right)\end{array}$ & $\begin{array}{c}T_{\text {in }}=15^{\circ} \mathrm{C}, P_{\text {in }}=1.013 \mathrm{bar} \\
m_{\text {air }}=121.3 \mathrm{~kg} / \mathrm{s} \\
T_{\text {out }}=129.1^{\circ} \mathrm{C}, P_{\text {out }}=39 \mathrm{bar}\end{array}$ & $\dot{W}_{A S U}$ \\
\hline 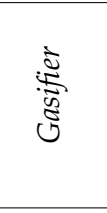 & $\begin{array}{c}\sum_{\text {in }} \omega_{\text {in }} \times \dot{m}_{\text {in }}=\sum_{\text {out }} \omega_{\text {out }} \times \dot{m}_{\text {out }} \\
Q_{\text {in }}+\sum_{\text {in }} \dot{m}_{h}=Q_{\text {out }}+\sum_{\text {out }} \dot{m}_{h} \\
\eta_{G}=\frac{L H V_{\text {syngas }} \times \dot{m}_{\text {syngas }}}{L H V_{\text {fuel }} \times \dot{m}_{\text {fuel }}}\end{array}$ & $\begin{array}{c}\sum_{i n} \dot{m}=79.6 \mathrm{~kg} / \mathrm{s} \\
L H V_{f u e l}=22,054.8 \mathrm{~kJ} / \mathrm{kg} \\
L H V_{\text {syngas }}=9549.7 \mathrm{~kJ} / \mathrm{kg}\end{array}$ & $\dot{m}_{\text {syngas }}^{\eta_{G}}$ \\
\hline 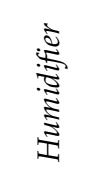 & $\begin{aligned} \sum_{\text {in }} \varphi_{\text {in }} \times \dot{m}_{\text {in }} & =\sum_{\text {out }} \varphi_{\text {out }} \times \dot{m}_{\text {out }} \\
\varphi & =\frac{\dot{m} v}{\dot{m}_{a}}\end{aligned}$ & $\begin{array}{c}\dot{m}_{\text {in }}=124.73 \mathrm{~kg} / \mathrm{s} \\
\varphi_{\text {in }}=0.862\end{array}$ & $\begin{array}{l}\dot{m}_{\text {out }} \\
\omega_{\text {out }}\end{array}$ \\
\hline 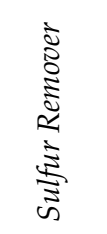 & $\begin{array}{c}\sum_{\text {in }} \varphi_{\text {in }} \times \dot{m}_{\text {in }}=\sum_{\text {out }} \varphi_{\text {out }} \times \dot{m}_{\text {out }} \\
\lambda=\frac{\dot{m}_{H_{2} S}}{\dot{m}_{\text {syngas }}}\end{array}$ & $\begin{array}{c}\dot{m}_{i n}=67.15 \mathrm{~kg} / \mathrm{s} \\
\lambda_{i n}=0.0025\end{array}$ & $\begin{array}{l}\dot{m}_{\text {out }} \\
\lambda_{\text {out }}\end{array}$ \\
\hline$\overbrace{\substack{n \\
0}}^{\frac{3}{3}}$ & $\begin{array}{c}\dot{m}_{\mathrm{CO} 2 . i n}=\frac{x_{\mathrm{CO} 2} M_{\mathrm{CO} 2}}{x_{\mathrm{CO} 2} M_{\mathrm{CO} 2}+x_{\mathrm{O} 2} M_{\mathrm{O} 2}+x_{\mathrm{H} 2 \mathrm{O}} M_{\mathrm{H} 2 \mathrm{O}}+x_{\mathrm{N} 2} M_{\mathrm{N} 2}} \times m_{f g} \\
\dot{m}_{\mathrm{CO} 2 . \text { out }}=\eta_{\mathrm{CO} 2 \text { Capture }} \dot{m}_{\mathrm{CO} 2 . i n} \\
Q_{\text {in }, \mathrm{CO} 2 \text { Capture }}=4.02 \times\left(\eta_{\mathrm{CO} 2 \text { Capture }} \times 100-0.00179\right) \\
E L_{\mathrm{CO} 2 \text { Capture }}=46.99+0.492 \times \eta_{\mathrm{CO} 2 \text { Capture }} \times 100 \\
W_{\mathrm{CO} 2 \text { Capture }}=0.44 \times\left(\eta_{\mathrm{CO} 2 \text { Capture }} \times 100-0.000179\right)\end{array}$ & $\begin{array}{c}T_{36}=T_{4}=T_{37} \\
P_{36}=P_{4} \\
T_{4}, P_{4} \\
\eta_{\text {CO2Capture }}\end{array}$ & $\begin{array}{c}\dot{m}_{\mathrm{CO} 2 . i n} \\
\dot{m}_{\mathrm{CO} 2 . \text { out }} \\
Q_{\text {in,CO2Capture }} \\
\text { EL } L_{\text {CO2Capture }} \\
W_{\text {CO2Capture }}\end{array}$ \\
\hline 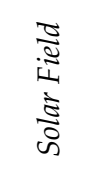 & $\begin{array}{c}P_{12}=P_{9}\left(1-d p_{S F}\right) \\
Q_{S F}=m_{9}\left(h_{12}-h_{9}\right) \\
A_{S F}=\frac{\dot{Q}_{S F}}{\eta_{S F} \times G}\end{array}$ & $\begin{aligned} T_{S}= & \left(T_{9}+T_{12}\right) / 2 \\
& d p_{S F} \\
& \eta_{S F}\end{aligned}$ & $\begin{array}{c}Q_{S F} \\
P_{12} \\
A_{S F} \\
T_{S}\end{array}$ \\
\hline 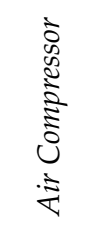 & $\begin{array}{c}W_{A C}=\dot{m}_{\text {air }}\left(h_{\text {out }}-h_{\text {in }}\right) \\
P_{\text {out }}=P_{\text {in }} \times r_{p, A C} \\
h_{\text {in }}=h_{\text {air } @ T_{\text {in }}}, h_{\text {ou }}=h_{\text {air } @ T_{\text {out }}} \\
T_{\text {out }}=T_{\text {in }} \times\left(1+\frac{1}{\eta_{A C}}\left(r_{p, A C} \frac{\gamma_{\text {air }}-1}{\gamma_{\text {air }}}-1\right)\right)\end{array}$ & $\begin{array}{c}T_{\text {in }}=25^{\circ} \mathrm{C}, P_{\text {in }}=1.013 \mathrm{bar} \\
r_{p, A C}=15.22 \\
c_{\text {air }}=1.005 \mathrm{~kJ} / \mathrm{kg} \cdot \mathrm{k} \\
\gamma_{\text {air }}=1.4 \\
\eta_{A C}=0.87\end{array}$ & $\begin{array}{c}W_{A C} \\
P_{2}\end{array}$ \\
\hline 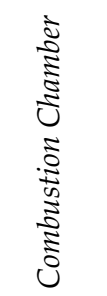 & $\begin{array}{c}\dot{m}_{\text {air }} h_{\text {air }}+\dot{m}_{\text {syngas }} L H V_{\text {syngas }} \eta_{C C}-\dot{m}_{f g} h_{f g}=0 \\
\dot{m}_{\text {air }}+\dot{m}_{\text {syngas }}-\dot{m}_{f g}=0 \\
P_{\text {out }}=P_{\text {in }}\left(1-\Delta P_{C C}\right)\end{array}$ & $\begin{array}{c}L H V_{\text {syngas }}=8976.8 \mathrm{~kJ} / \mathrm{kg} \\
T_{\text {in }}=396.9^{\circ} \mathrm{C}, P_{\text {in }}=15.426 \mathrm{bar} \\
\Delta P_{C C}=0.04 \\
\dot{m}_{\text {air }}=492 \mathrm{~kg} / \mathrm{s} \\
\eta_{C C}=95 \%\end{array}$ & $\begin{array}{c}T_{\text {out }}, P_{\text {out }} \\
\dot{m}_{\text {syngas }}, \dot{m}_{f g}\end{array}$ \\
\hline
\end{tabular}


Table A1. Cont.

\begin{tabular}{|c|c|c|c|}
\hline Comp. & Relations & Process Conditions & $\begin{array}{l}\text { Unknown } \\
\text { Parameters }\end{array}$ \\
\hline 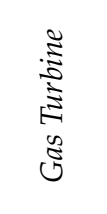 & $\begin{array}{c}W_{G T}=\dot{m}_{f g}\left(h_{\text {in }}-h_{\text {out }}\right) \\
T_{\text {out }}=T_{\text {in }} \times\left(1-\eta_{G T}\left(1-r_{p, G T}{ }^{\frac{1-\gamma_{\text {air }}}{\gamma_{\text {air }}}}\right)\right) \\
P_{\text {out }}=P_{\text {in }}+\sum_{\text {in }} \Delta P_{H R S G, f g} \\
W_{\text {net }, g c}=W_{G T}-W_{A C}\end{array}$ & $\begin{array}{c}T_{3}=1300^{\circ} \mathrm{C}, P_{3}=14.833 \mathrm{bar} \\
\dot{m}_{f g}=563.1 \mathrm{~kg} / \mathrm{s} \\
\eta_{G T}=88 \% \\
r_{p, G T}=14.52\end{array}$ & $\begin{array}{c}W_{G T} \\
T_{20}\end{array}$ \\
\hline 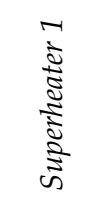 & $\begin{array}{c}\dot{m}_{f g}\left(h_{35}-h_{23}\right)+\dot{m}_{h p}\left(h_{33}-h_{32}\right)=0 \\
P_{23}=P_{35}-\Delta P_{H P S H, f g} \\
P_{33}=P_{32}-\Delta P_{H P S H, s} \\
Q_{H P S H}=\dot{m}_{h p}\left(h_{33}-h_{32}\right) \\
h_{32}=h_{\text {water@ }} T_{32}, P_{32}\end{array}$ & $\begin{array}{c}\Delta P_{H P S H, f g}=2.491 \text { millibar } \\
\Delta P_{H P S H, S}=2.41 \text { millibar } \\
T_{H P S H}=535^{\circ} \mathrm{C} \\
T_{32}=326.2^{\circ} \mathrm{C} \\
P_{32}=122.4 \text { bar }\end{array}$ & $\begin{array}{c}Q_{H P S H} \\
T_{23}, P_{23} \\
T_{33}, P_{33} \\
\dot{m}_{h p}\end{array}$ \\
\hline 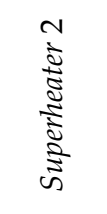 & $\begin{array}{c}\dot{m}_{f g}\left(h_{15}-h_{13}\right)+\dot{m}_{h p}\left(h_{38}-h_{40}\right)=0 \\
P_{38}=P_{40}-\Delta P_{H P S H, f g} \\
P_{13}=P_{15}-\Delta P_{H P S H, s} \\
Q_{H P S H}=\dot{m}_{h p}\left(h_{38}-h_{40}\right)\end{array}$ & $\begin{array}{c}T_{15}=608^{\circ} \mathrm{C}, P_{15}=0.88 \text { bar } \\
\Delta P_{H P S H, f g}=2.491 \text { millibar } \\
\Delta P_{H P S H, s}=2.41 \text { millibar } \\
T_{40}=351.28^{\circ} \mathrm{C} \\
P_{40}=39.78 \text { bar }\end{array}$ & $\begin{array}{c}Q_{H P S H} \\
T_{13}, P_{13} \\
T_{38}, P_{38} \\
\dot{m}_{h p 2}\end{array}$ \\
\hline  & $\begin{array}{c}\dot{m}_{f g}\left(h_{23}-h_{30}\right)+\dot{m}_{h p}\left(h_{32}-h_{31}\right)=0 \\
P_{30}=P_{23}-\Delta P_{H P E V, f g} \\
P_{32}=P_{31}-\Delta P_{H P E V, s} \\
Q_{H P E V}=\dot{m}_{h p}\left(h_{32}-h_{31}\right)\end{array}$ & $\begin{array}{c}T_{20}=556.8^{\circ} \mathrm{C}, P_{20}=1.0205 \text { bar } \\
\Delta P_{H P E C, f g}=2.4911 \text { millibar } \\
\Delta P_{H P E C, s}=2.4481 \text { milli } \\
T_{24}=260^{\circ} \mathrm{C}, P_{24}=122.4 \text { bar } \\
\Delta P_{H P E V, f g}=4.9811 \text { millibar }\end{array}$ & $\begin{array}{l}Q_{H P E V} \\
T_{23}, P_{23}\end{array}$ \\
\hline 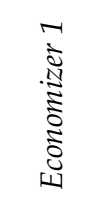 & $\begin{array}{c}\dot{m}_{f g}\left(h_{30}-h_{18}\right)+\dot{m}_{h p}\left(h_{31}-h_{41}\right)=0 \\
P_{18}=P_{30}-\Delta P_{H P E C 2, f g} \\
P_{41}=P_{31}-\Delta P_{H P E C 2, s} \\
T_{26}=T_{s a t @ P_{26}} \\
Q_{H P E C 2}=\dot{m}_{h p}\left(h_{24}-h_{26}\right)\end{array}$ & $\begin{array}{c}T_{41}=340.5^{\circ} \mathrm{C}, P_{6}=1.0155 \mathrm{bar} \\
\Delta P_{H P E C, f g}=2.4911 \text { millibar } \\
\Delta P_{H P E C, s}=2.4481 \text { millibar } \\
T_{30}=366.8^{\circ} \mathrm{C}, P_{28}=0.88 \mathrm{bar}\end{array}$ & $\begin{array}{l}Q_{H P E C 2} \\
T_{41}, P_{41} \\
T_{18}, P_{18}\end{array}$ \\
\hline 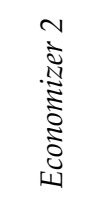 & $\begin{array}{c}\dot{m}_{f g}\left(h_{13}-h_{25}\right)+\dot{m}_{h p}\left(h_{11}-h_{1}\right)=0 \\
T_{1}=T_{\text {sat }} @ P_{1} Q_{H P E C 2}=\dot{m}_{h p}\left(h_{11}-h_{1}\right)\end{array}$ & $\begin{aligned} P_{31} & =122.4 \mathrm{bar} \\
T_{31} & =310.4{ }^{\circ} \mathrm{C} \\
\triangle P_{H P E C, f g} & =2.4911 \text { millibar } \\
\triangle P_{H P E C, s} & =2.4481 \text { millibar }\end{aligned}$ & $\begin{array}{l}Q_{H P E C 2} \\
T_{11}, P_{11} \\
T_{25}, P_{25}\end{array}$ \\
\hline 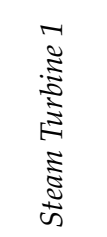 & $\begin{array}{c}\dot{m}_{33} h_{33}-\dot{m}_{27} h_{27}-W_{S T 1}=0 \\
h_{27}=h_{33}-\eta_{S T}\left(h_{33}-h_{27}\right) \\
\dot{m}_{33}-\dot{m}_{27}=0\end{array}$ & $\eta_{S T}=88 \%$ & $\begin{array}{c}W_{S T 1} \\
T_{27}, P_{27}\end{array}$ \\
\hline 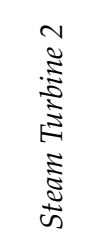 & $\begin{array}{c}\dot{m}_{38} h_{38}-\dot{m}_{21} h_{21}-W_{S T 2}=0 \\
h_{21}=h_{38}-\eta_{S T}\left(h_{38}-h_{21 s}\right) \\
\dot{m}_{38}-\dot{m}_{21}=0\end{array}$ & $\eta_{S T}=88 \%$ & $\begin{array}{c}W_{S T 2} \\
T_{21}, P_{21}\end{array}$ \\
\hline
\end{tabular}


Table A1. Cont.

\begin{tabular}{|c|c|c|c|}
\hline Comp. & Relations & Process Conditions & $\begin{array}{l}\text { Unknown } \\
\text { Parameters }\end{array}$ \\
\hline 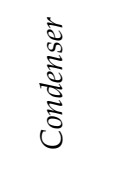 & $\begin{array}{c}\dot{m}_{f w}\left(h_{21}-h_{22}\right)+\dot{m}_{c w}\left(h_{39}-h_{29}\right)=0 \\
Q_{\text {cond }}=\dot{m}_{f w}\left(h_{21}-h_{22}\right) \\
T_{39}=T_{29}+\Delta T_{C W} \\
P_{39}=P_{29}-\Delta P_{\text {cond }}\end{array}$ & $\begin{array}{c}T_{21}=38.74^{\circ} \mathrm{C}, \quad P_{21}=0.07 \mathrm{bar} \\
T_{29}=25^{\circ} \mathrm{C}, P_{29}=1.023 \mathrm{bar} \\
\Delta T_{C W}=15.5^{\circ} \mathrm{C}\end{array}$ & $\begin{array}{c}Q_{\text {cond }} \\
\dot{m}_{c w} \\
T_{21}, P_{21} \\
T_{39}, P_{39}\end{array}$ \\
\hline  & $W_{E X}=m \times c_{p} \times\left(T_{28}-T_{16}\right)$ & $\begin{array}{c}m=28.29 \mathrm{~kg} / \mathrm{s} \\
T_{28}=519.05^{\circ} \mathrm{C} \\
C_{P}=1.62 \mathrm{~kJ} / \mathrm{kg} \cdot \mathrm{K}\end{array}$ & $\begin{array}{c}W_{E X} \\
T_{16}\end{array}$ \\
\hline
\end{tabular}

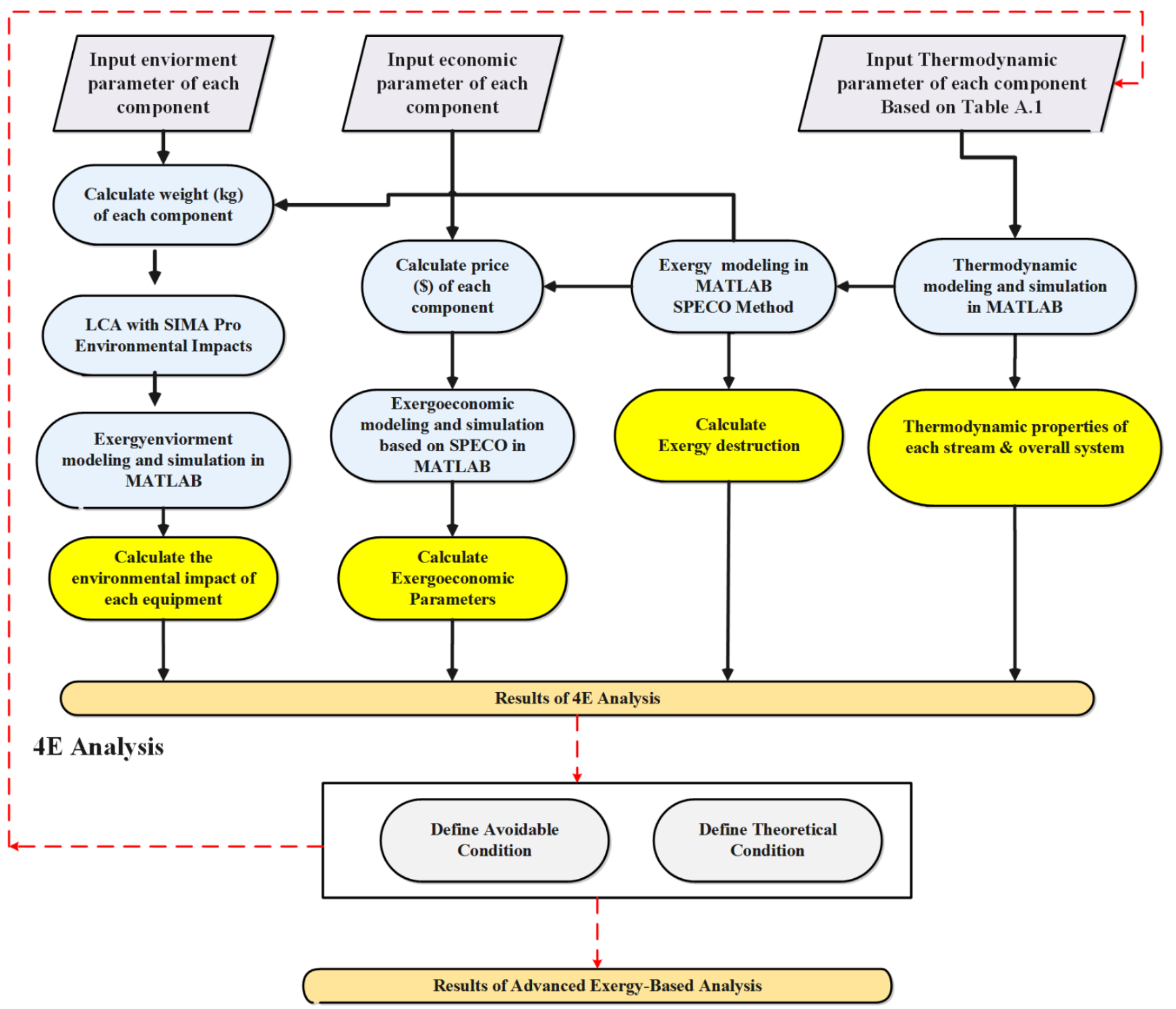

Figure A1. Schematic of computational procedure for $4 \mathrm{E}$ and advanced exergy-based analyses. 
Table A2. Exergy destruction and exergy efficiency formulation [17].

\begin{tabular}{|c|c|c|}
\hline Component & Exergy Destruction & Exergy Efficiency \\
\hline Air separation unit & $E x 14-E x 5+W_{A S U}$ & $\frac{E x 5-E x 14}{W_{A S U}}$ \\
\hline Solar field & $E x 9-E x 12+E x_{S F}$ & $\frac{E x 12-E x 9}{E x_{S F}}$ \\
\hline Gasifier & $E x 5+E x 12+E x 8-E x_{\text {gasi }}$ & $\frac{E x_{\text {gasi }}}{E x 5+E x 12+E x 8}$ \\
\hline Syngas cooler & $E x_{\text {gasi }}+E x 11-E x 6-E x 34$ & $\frac{E x 34-E x 11}{E x_{g a s i}-E x 6}$ \\
\hline Heat exchanger & $E x 6+E x 19-E x 10-E x 28$ & $\frac{E \times 28-E \times 19}{E \times 6-E \times 10}$ \\
\hline $\mathrm{H}_{2} \mathrm{~S}$ remover & $E x 10-E x 17-E x 4$ & $\frac{E x 17}{E x 10-E x 4}$ \\
\hline $\mathrm{CO}_{2}$ capture & $E x 4-E \times 37-E x 36$ & $\frac{E x 37}{E x 4-E \times 36}$ \\
\hline Humidifier & $E x 36+E x 7-E x 19-E x_{\text {Humidifier }}$ & $\frac{E x_{\text {scr } \text { out }}+E x 19}{E x 7+E x 36}$ \\
\hline Expander & $E x 28-E x 16-W_{e x p}$ & $\frac{W_{E x p}}{E x 28-E x 16}$ \\
\hline Combustion chamber & Exacout - Exccout + Ex16 & $\frac{\text { Exccout }}{\text { Exacout }+ \text { Ex16 }}$ \\
\hline Air compressor & Ex14-Exacout $+W_{A C}$ & $\frac{\text { Exacout-Ex14 }}{W_{A C}}$ \\
\hline Gas turbine & Exccout $-E x 20-W_{G T}$ & $\frac{W_{G T}}{\text { Exccout }-E x 20}$ \\
\hline Superheater & $E x 35+E x 32-E x 23-E x 33$ & $\frac{E \times 33-E x 32}{E x 35-E x 23}$ \\
\hline Evaporator & $E x 23+E x 31-E x 30-E x 32$ & $\frac{E x 32-E x 31}{E \times 23-E x 30}$ \\
\hline HRSG & $E x 42+E x 30-E x 18-E x 31$ & $\frac{E \times 31-E \times 42}{E \times 30-E x 18}$ \\
\hline Steam turbine & $E \times 33-E \times 27-W_{S T}$ & $\frac{W_{S T}}{E \times 33-E x 27}$ \\
\hline Condenser & $E x 29+E x 21-E x 39-E x 22$ & $\frac{E \times 39-E \times 29}{E \times 21-E \times 22}$ \\
\hline
\end{tabular}

HRSG: Heat recovery steam generator.

Table A3. Purchase equipment cost for the different ISGC system components [17].

\begin{tabular}{|c|c|}
\hline Component & Purchase Equipment Cost Relations \\
\hline ASU & $\begin{aligned} P E C_{A S U}= & (\text { Ref Cost }) \times\left(\frac{\text { Size }}{\text { Ref Size }}\right){ }^{\text {Scalling Exponent }} \times(\text { Overal Installation Factor }) \\
& \text { Scalling Exponent }=0.5, \text { Overal Installation Factor }=1 \\
& \text { Ref Cost }=141 \text { Million US } \$ \text { Ref Size }=52 \mathrm{~kg} \mathrm{O}_{2} / \mathrm{s}\end{aligned}$ \\
\hline Solar field & $P E C_{\text {Solarfield }}=355 \$ / \mathrm{m}^{2}$ \\
\hline Gasifier & $\begin{aligned} \text { PEC }_{\text {GASI }}= & (\text { Ref Cost }) \times\left(\frac{\text { Size }}{\text { Ref Size }}\right){ }^{\text {Scalling Exponent }} \times(\text { Overal Installation Factor }) \\
& \text { Scalling Exponent }=0.7, \text { Overal Installation Factor }=1 \\
& \text { Ref Cost }=395 \text { Million US } \$ \text {, Ref Size }=68.5 \mathrm{~kg} \text { feed } / \mathrm{s}\end{aligned}$ \\
\hline Syngas cooler & $P E C_{S y n \_c o o l e r}=12,000\left(\frac{A}{100}\right)^{0.6}$ \\
\hline Heat exchanger & $P E C_{H X}=12,000\left(\frac{A}{100}\right)^{0.6}$ \\
\hline $\mathrm{H}_{2} \mathrm{~S} / \mathrm{CO}_{2}$ remover & $\begin{array}{c}P E C_{\text {Cleaner }}=(\text { Ref Cost }) \times\left(\frac{\text { Size }}{\text { Ref Size }}\right) \\
\quad \times(\text { Overalling Exponent } \\
\quad=0.63, \text { Overallation Factor }) \text { Scalling Exponent } \\
\text { Ref Cost }=28.8 \text { Million US } \$ \text {, Ref Size }=2.48 \mathrm{kmole} \text { feed } / \mathrm{s}\end{array}$ \\
\hline Expansion turbine & $P E C_{\text {Expander }}=W_{\text {Turb }}\left(1318.5-98.328 \ln \left(W_{\text {Turb }}\right)\right)$ \\
\hline Combustion chamber & $P E C_{C C}=\frac{28.98 \mathrm{~m}_{a}}{0.995-\frac{p_{\text {out }}}{p_{\text {in }}}} \cdot\left(1+\mathrm{e}^{\left(0.015\left(T_{\text {out }}-1540\right)\right)}\right)$ \\
\hline Air compressor & $P E C_{\text {Compressor }}=44.71 m_{a} \cdot r_{p, A C} \cdot \ln \left(r_{p, A C}\right) \cdot \frac{1}{0.95-\eta_{A C}}$ \\
\hline Gas turbine & $P E C_{G T}=479.34 \frac{m_{f g}}{0.93-\eta_{G T}} \cdot \ln \left(r_{p, G T}\right) \cdot\left(1+\mathrm{e}^{\left(0.036 * \mathrm{~T}_{\text {in }}-54.4\right)}\right)$ \\
\hline
\end{tabular}


Table A3. Cont.

\section{Component}

HRSG

Steam turbine

Condenser

\section{Purchase Equipment Cost Relations}

$$
P E C_{H R S G}=6570\left[\left(\frac{Q_{E C}}{\Delta T_{E C}}\right)^{0.8}+\left(\frac{Q_{E V}}{\Delta T_{E V}}\right)^{0.8}+\left(\frac{Q_{S H}}{\Delta T_{S H}}\right)^{0.8}\right]+21,276 m_{w}+1184.4 m_{f g}^{1.2}
$$

$$
\begin{aligned}
& P E C_{S T}=2210 . \dot{W}^{0.7} \\
& P E C_{\text {Cond }}=1773 . \dot{m}
\end{aligned}
$$

\begin{tabular}{|c|c|}
\hline Component & Exergoeconomic Balance \\
\hline Air separation unit & $\dot{Z}_{A S U}=C 5 \times E x 5-C_{G T} \times W_{A S U}$ \\
\hline Solar field & $\dot{Z}_{Q S F}=C 12 \times E x 12$ \\
\hline Gasifier & $\dot{Z}_{G A S I}+C 8 \times E x 8=C_{G A S I} \times E x_{G A S I}-C 5 \times E x 5-C 12 \times E x 12$ \\
\hline Syngas cooler & $\dot{Z}_{\text {syn-cooler }}+C_{G A S I}\left(E x_{G A S I}-E x 6\right)=C 34 \times E x 34$ \\
\hline Heat exchanger & $\dot{Z}_{H X}=C_{G A S I}(E x 10-E x 4)-C 19 \times E x 19+C 28 \times E x 28$ \\
\hline $\mathrm{H}_{2} \mathrm{~S}$ remover & $\dot{Z}_{\mathrm{H}_{2} S \_ \text {Remover }}=C_{G A S I}(E x 17-E x 10)+C 4 \times E x 4$ \\
\hline $\mathrm{CO}_{2}$ capture & $\dot{Z}_{\mathrm{CO}_{2} \text { Capture }}=\mathrm{C} 4(E \times 37-E x 4)+C 36 \times E \times 36$ \\
\hline Humidifier & $\dot{Z}_{S C R}=C 19 \times E x 19-C 36 \times E x 36$ \\
\hline Expander & $\dot{Z}_{E X P}=C 28(E x 16-E x 28)+C_{E X P} \times W_{E X P}$ \\
\hline Combustion chamber & $\dot{Z}_{C C}=C_{c c o u t} \times E x_{c c o u t}-C 28 \times E x 16-C_{a c o u t} \times E x_{a c o u t}$ \\
\hline Air compressor & $\dot{Z}_{A C}=C_{\text {acout }} \times E x_{\text {acout }}-C_{G T} \times W_{A C}$ \\
\hline Gas turbine & $\dot{Z}_{G T}=C_{c c o u t}\left(E x 20-E x_{c c o u t}\right)+C_{G T} \times W_{G T}$ \\
\hline Superheater & $\dot{Z}_{S H}+C 20(E x 35-E x 23)=C 33 \times E x 33-C 32 \times E x 32$ \\
\hline Evaporator & $\dot{Z}_{E V}+C 20(E x 23-E x 30)=C 32 \times E x 32-C 31 \times E x 31$ \\
\hline HRSG & $\dot{Z}_{E c o}+C 20 \times E x 30=C 31 \times E x 31$ \\
\hline Steam turbine & $\dot{Z}_{S T}=C 33(E x 27-E x 31)+C_{S T} \times W_{S T}$ \\
\hline Condenser & $\dot{Z}_{\text {Cond }}=C 38(E \times 22-E x 21)+C 39 \times E x 39$ \\
\hline
\end{tabular}

HRSG: Heat recovery steam generator.

Table A4. Exergoeconomic formulation for the different ISGC system components [17].

HRSG: Heat recovery steam generator.

Table A5. Weight of different system components [36,41].

\section{Component}

Air separation unit

Solar field

Gasifier

\section{Weight (tons)}

$W_{A S U}=0.0061 \times \dot{W}_{A S U_{\text {Total }}}^{0.95} ; \dot{\mathrm{W}}$ in $\mathrm{kW}$
$W_{\text {coll }}=0.0626 . L($ length $) ; \mathrm{L}$ in $\mathrm{m}$
$W_{\text {Gasifier }}=\frac{100 \times P_{e} \times d_{\text {Gasifier }} \times F S_{\text {Gasifier }}}{2 \times \sigma_{\text {Gasifier }}}$

$\mathrm{FS}_{\text {Gasifier }}=2$ : safety factorof Gasifier

$\sigma_{\text {Gasifier }}=45$ : rupturing stress of Gasifierin $\mathrm{MPa}$

$d_{\text {Gasifier }}$ : diameter consideringm and velocity $=6.2 \mathrm{~m} / \mathrm{s}$

Syngas cooler

$W_{\text {syn_cooler }}=13.91 *\left(Q_{\text {syn_cooler }} / 1000\right)^{0.68}$;

Heat exchanger

$W_{H X}=2.989 \times \dot{Q}_{H X}^{0.97} ; \dot{Q}$ inMW

$\mathrm{H}_{2} \mathrm{~S} / \mathrm{CO}_{2}$ remover 
Table A5. Cont.

\section{Component}

Expander
Weight (tons)

$W_{E X P}=\frac{100 \times P_{e} \times d_{E X P} \times F S_{E X P}}{2 \times \sigma_{E X P}}$

$\mathrm{FS}_{E X P}=2$ : safety factor of $E X P$

$\sigma_{E X P}=6:$ rupturing stress of EXP in $\mathrm{MPa}$

$d_{E X P}$ : diameter consideringm and velocity $=13 \mathrm{~m} / \mathrm{s}$
Combustion chamber

Air compressor

$$
W_{C C}=\frac{100 \times P_{e} \times d_{C C} \times F S_{C C}}{2 \times \sigma_{C C}}
$$

$\mathrm{FS}_{\mathrm{CC}}=2$ : safety factor of $\mathrm{CC}$

$\sigma_{C C}=45:$ rupturing stress of $\mathrm{CC}$ in $\mathrm{MPa}$

$d_{C C}$ : diameter consideringm and velocity $=6.2 \mathrm{~m} / \mathrm{s}$

$W_{A C}=\frac{100 \times P_{e} \times d_{A C} \times F S_{A C}}{2 \times \sigma_{A C}}$

$\mathrm{FS}_{A C}=2:$ safety factor of $\mathrm{AC}$

$\sigma_{A C}=16$ : rupturing stress of $\mathrm{AC}$ in $\mathrm{MPa}$

$d_{A C}:$ diameter consideringm and velocity $=15 \mathrm{~m} / \mathrm{s}$

$$
W_{G T}=\frac{100 \times P_{e} \times d_{G T} \times F S_{G T}}{2 \times \sigma_{G T}}
$$

$\mathrm{FS}_{G T}=2:$ safety factor of GT

Gas turbine

$\sigma_{G T}=6:$ rupturing stress of $\mathrm{GT}$ in $\mathrm{MPa}$

$d_{G T}:$ diameter consideringm and velocity $=13 \mathrm{~m} / \mathrm{s}$

Superheater

Evaporator

HRSG

Steam turbine

Condenser

$$
\begin{gathered}
W_{S H}=8.424 \times \dot{Q}_{S H}^{0.87} ; \dot{Q} \text { inMW } \\
W_{E V}=13.91 \times \dot{Q}_{E V}^{0.68} ; \dot{\text { QinMW }} \\
W_{E C}=2.989 \times \dot{Q}_{E C}^{0.97} ; \dot{Q} \text { inMW } \\
W_{S T}=4.9 \times \dot{W}_{S T}^{0.73} \\
W_{\text {cond }}=0.073 \times \dot{Q}^{0.99} ; \dot{Q} \text { inMW }
\end{gathered}
$$

HRSG: Heat recovery steam generator.

Table A6. Environmental impact rate formulation for the different ISGC system components [17].

\section{Component}

Air separation unit

Solar field

Gasifier

Syngas cooler

Heat exchanger

$\mathrm{H}_{2} \mathrm{~S}$ remover

$\mathrm{CO}_{2}$ capture

Humidifier

Expander

Combustion chamber

Air compressor

Gas turbine

Superheater

Evaporator

HRSG

Steam turbine

Condenser

\section{Environmental Impact Rate Balances}

$W_{A S U}=b 5 \times E x 5-b_{G T} \times \dot{W}_{A S U}$

$W_{\text {SolarField }}=b 12 \times E x 12$

$W_{G A S I}+b 8 \times E x 8=b_{G A S I} \times E x_{G A S I}-b 5 \times E x 5-b 12 \times E x 12$

$$
W_{\text {syn-cooler }}+b_{G A S I}\left(E x_{G A S I}-E x 6\right)=b 34 \times E x 34
$$

$W_{H X}=b_{G A S I}(E x 10-E x 4)-b 19 \times E x 19+b 28 \times E x 28$

$W_{H_{2} S \_R e m o v e r}=b_{G A S I}(E x 17-E x 10)+b 4 \times E x 4$

$W_{\mathrm{CO}_{2} \text { Capture }}=b 4(E x 37-E x 4)+b 36 \times E x 36$

$W_{S C R}=b 19 \times E x 19-b 36 \times E x 36$

$W_{E X P}=b 28(E x 16-E x 28)+b_{E X P} \times \dot{W}_{E X P}$

$W_{C C}=b_{\text {ccout }} \times E x_{\text {ccout }}-b 28 \times E x 16-b_{\text {acout }} \times E x_{\text {acout }}$

$W_{A C}=b_{\text {acout }} \times E x_{\text {acout }}-b_{G T} \times \dot{W}_{A C}$

$W_{G T}=b_{\text {ccout }}\left(E x 20-E x_{\text {ccout }}\right)+b_{G T} \times \dot{W}_{G T}$

$W_{S H}+b 20(E x 35-E x 23)=b 33 \times E x 33-b 32 \times E x 32$

$W_{E V}+b 20(E x 23-E x 30)=b 32 \times E x 32-b 31 \times E x 31$

$W_{E c o}+b 20 \times E x 30=b 31 \times E x 31$

$W_{S T}=b 33(E \times 27-E \times 31)+b_{S T} \times \dot{W}_{S T}$

$W_{\text {Cond }}=b 38(E \times 22-E \times 21)+b 39 \times E \times 39$ 


\section{References}

1. Kamińska-Pietrzak, N.; Smoliński, A. Selected environmental aspects of gasification and co-gasification of various types of waste. J. Sustain. Min. 2013, 12, 6-13. [CrossRef]

2. Bany Ata, A.; Seufert, P.M.; Heinze, C.; Alobaid, F.; Epple, B. Optimization of integrated gasification combined-cycle power plant for polygeneration of power and chemicals. Energies 2021, 14, 7285. [CrossRef]

3. Muhammad, A.; Muhammad, Z.; Ullah, A.; Muhammad, R.; Ramzan, N. Thermo-economic analysis of integrated gasification combined cycle co-generation system with carbon capture and integrated with absorption refrigeration system. Energy Convers. Manag. 2021, 248, 114782. [CrossRef]

4. Ren, S.; Feng, X.; Wang, Y. Emergy evaluation of the integrated gasification combined cycle power generation systems with a carbon capture system. Renew. Sustain. Energy Rev. 2021, 147, 111208. [CrossRef]

5. Szima, S.; Arnaiz del Pozo, C.; Cloete, S.; Chiesa, P.; Jiménez Alvaro, Á.; Cormos, A.M.; Amini, S. Finding synergy between renewables and coal: Flexible power and hydrogen production from advanced IGCC plants with integrated $\mathrm{CO}_{2}$ capture. Energy Convers. Manag. 2021, 231, 113866. [CrossRef]

6. Liu, K.; Song, C.; Subramani, V. Hydrogen and syngas production and purification technologies. Hydrog. Syngas Prod. Purif. Technol. 2009, 1, 1-533. [CrossRef]

7. Wang, T.; Stiegel, G. Integrated Gasification Combined Cycle (IGCC) Technologies; Elsevier: Amsterdam, The Netherlands, 2016. ISBN 9780081001851.

8. Hoang, T.-D.; Pawluskiewicz, D.K. The efficiency analysis of different combined cycle power plants based on the impact of selected parameters. Int. J. Smart Grid Clean Energy 2016, 5, 77-85. [CrossRef]

9. Hamour, N.; Bidarian, A.; Sandall, O.C. Simultaneous absorption of $\mathrm{H} 2 \mathrm{~s}$ and $\mathrm{CO}_{2}$ into Aqueous Methyldiethanolamine. Sep. Sci. Technol. 2012, 22, 921-947. [CrossRef]

10. Marcantonio, V.; Bocci, E.; Ouweltjes, J.P.; Del Zotto, L.; Monarca, D. Evaluation of sorbents for high temperature removal of tars, hydrogen sulphide, hydrogen chloride and ammonia from biomass-derived syngas by using Aspen Plus. Int. J. Hydrog. Energy 2020, 45, 6651-6662. [CrossRef]

11. Hasegawa, T.; Sato, M.; Katsuki, Y.; Hisamatsu, T. Study of medium-btu fueled gas turbine combustion technology for reducing both fuel-nox and thermal-nox emissions in oxygen-blown IGCC. ASME. Int. Gas Turbine Inst. 2009, 1, 239-256. [CrossRef]

12. Nag, P.K.; De, S. Study of thermodynamic performance of an integrated gasification combined cycle power plant. PIME J. Power Energy 1998, 212, 89-95. [CrossRef]

13. Emun, F.; Gadalla, M.; Jiménez, L. Integrated Gasification Combined Cycle (IGCC) Process Simulation and Optimization. In Computer Aided Chemical Engineering; Elsevier: Amsterdam, The Netherlands, 2008; pp. 1059-1064.

14. Domenichini, R.; Gallio, M.; Lazzaretto, A. Combined production of hydrogen and power from heavy oil gasification: Pinch analysis, thermodynamic and economic evaluations. Energy 2010, 35, 2184-2193. [CrossRef]

15. Morini, M.; Pinelli, M.; Spina, P.R.; Vaccari, A.; Venturini, M. Feasibility analysis of gas turbine inlet air cooling by means of liquid nitrogen evaporation for IGCC power augmentation. Appl. Therm. Eng. 2015, 80, 168-177. [CrossRef]

16. Zhang, Y.; Ahn, H. The implications of choice between sour and sweet shift on process design and operation of an IGCC power plant integrated with a dual-stage selexol unit. Energy 2019, 173, 1273-1284. [CrossRef]

17. Khoshgoftar Manesh, M.H.; Jadidi, E. Conventional and Advanced Exergy, Exergoeconomic and Exergoenvironmental Analysis of a Biomass Integrated Gasification Combined Cycle Plant. In Energy Sources, Part A Recovery Utilization and Environmental. Effects; Taylor and Francis Ltd.: London, UK, 2020; pp. 1-22. [CrossRef]

18. Jia, J.; Abudula, A.; Wei, L.; Sun, B.; Shi, Y. Thermodynamic modeling of an integrated biomass gasification and solid oxide fuel cell system. Renew. Energy 2015, 81, 400-410. [CrossRef]

19. Doherty, W.; Reynolds, A.; Kennedy, D. Process simulation of biomass gasification integrated with a solid oxide fuel cell stack. J. Power Sources 2015, 277, 292-303. [CrossRef]

20. Chen, S.; Lior, N.; Xiang, W. Coal gasification integration with solid oxide fuel cell and chemical looping combustion for high-efficiency power generation with inherent $\mathrm{CO}_{2}$ capture. Appl. Energy 2015, 146, 298-312. [CrossRef]

21. Wang, J.-J.; Yang, K.; Xu, Z.-L.; Fu, C. Energy and exergy analyses of an integrated CCHP system with biomass air gasification. Appl. Energy 2015, 142, 317-327. [CrossRef]

22. Athari, H.; Soltani, S.; Bölükbaşi, A.; Rosen, M.A.; Morosuk, T. Comparative exergoeconomic analyses of the integration of biomass gasification and a gas turbine power plant with and without fogging inlet cooling. Renew. Energy 2015, 76, 394-400. [CrossRef]

23. Perna, A.; Minutillo, M.; Jannelli, E. Hydrogen from intermittent renewable energy sources as gasification medium in integrated waste gasification combined cycle power plants: A performance comparison. Energy 2016, 94, 457-465. [CrossRef]

24. Yari, M.; Mehr, A.S.; Mahmoudi, S.M.S.; Santarelli, M. A comparative study of two SOFC based cogeneration systems fed by municipal solid waste by means of either the gasifier or digester. Energy 2016, 114, 586-602. [CrossRef]

25. Lv, X.; Liu, X.; Gu, C.; Weng, Y. Determination of safe operation zone for an intermediate-temperature solid oxide fuel cell and gas turbine hybrid system. Energy 2016, 99, 91-102. [CrossRef]

26. Thattai, A.T.; Oldenbroek, V.; Schoenmakers, L.; Woudstra, T.; Aravind, P.V. Experimental model validation and thermodynamic assessment on high percentage (up to $70 \%$ ) biomass co-gasification at the $253 \mathrm{MW}$ integrated gasification combined cycle power plant in Buggenum, The Netherlands. Appl. Energy 2016, 168, 381-393. [CrossRef] 
27. Khani, L.; Mahmoudi, S.M.S.; Chitsaz, A.; Rosen, M.A. Energy and exergoeconomic evaluation of a new power/cooling cogeneration system based on a solid oxide fuel cell. Energy 2016, 94, 64-77. [CrossRef]

28. Park, S.; Kim, J.; Yoon, M.; Rhim, D.; Yeom, C. Thermodynamic and economic investigation of coal-fired power plant combined with various supercritical $\mathrm{CO}_{2}$ Brayton power cycle. Appl. Therm. Eng. 2018, 130, 611-623. [CrossRef]

29. Zhang, G.; Yang, Y.; Jin, H.; Xu, G.; Zhang, K. Proposed combined-cycle power system based on oxygen-blown coal partial gasification. Appl. Energy 2013, 102, 735-745. [CrossRef]

30. Gharagheizi, F.; Mehrpooya, M. Prediction of standard chemical exergy by a three descriptors QSPR model. Energy Convers. Manag. 2007, 48, 2453-2460. [CrossRef]

31. Lazzaretto, A.; Tsatsaronis, G. SPECO: A systematic and general methodology for calculating efficiencies and costs in thermal systems. Energy 2006, 31, 1257-1289. [CrossRef]

32. Dincer, I.; Rosen, M.A.; Ahmadi, P. Optimization of Energy Systems; Wiley: New York, NY, USA, 2017.

33. Bejan, A.; Tsatsaronis, G.; Moran, M.J. Thermal Design and Optimization; Wiley: New York, NY, USA, 1996.

34. Cao, Y.; Dhahad, H.A.; Sun, Y.-L.; Abdollahi Haghghi, M.; Delpisheh, M.; Athari, H.; Farouk, N. The role of input gas species to the cathode in the oxygen-ion conducting and proton conducting solid oxide fuel cells and their applications: Comparative 4E analysis. Int. J. Hydrog. Energy 2021. [CrossRef]

35. Goedkoop, M.; Spriensma, R.; Effting, S.; Collignon, M. The Eco-Indicator 99: A Damage Oriented Method for Life-Cycle Impact Assessment: Methodology Report, 3rd ed.; PRé Consultants: Amersfoort, The Netherlands, 2001.

36. Cavalcanti, E.J.C. Exergoeconomic and exergoenvironmental analyses of an integrated solar combined cycle system. Renew. Sustain. Energy Rev. 2017, 67, 507-519. [CrossRef]

37. Razi, F.; Dincer, I.; Gabriel, K. Exergoenvironmental analysis of the integrated copper-chlorine cycle for hydrogen production. Energy 2021, 226, 120426. [CrossRef]

38. Mehrpooya, M.; Raeesi, M.; Pourfayaz, F.; Delpisheh, M. Investigation of a hybrid solar thermochemical water-splitting hydrogen production cycle and coal-fueled molten carbonate fuel cell power plant. Sustain. Energy Technol. Assess. 2021, 47, 101458. [CrossRef]

39. Tsatsaronis, G. Recent developments in exergy analysis and exergoeconomics. Int. J. Exergy 2008, 5, 489-499. [CrossRef]

40. Kelly, S.; Tsatsaronis, G.; Morosuk, T. Advanced exergetic analysis: Approaches for splitting the exergy destruction into endogenous and exogenous parts. Energy 2009, 34, 384-391. [CrossRef]

41. Boyano, A.; Morosuk, T.; Blanco-Marigorta, A.M.; Tsatsaronis, G. Conventional and advanced exergoenvironmental analysis of a steam methane reforming reactor for hydrogen production. J. Clean. Prod. 2012, 20, 152-160. [CrossRef] 